\title{
Recent Trends in Removal Pharmaceuticals and Personal Care Products by Electrochemical Oxidation and Combined Systems
}

\author{
Khanh Chau Dao ${ }^{1,2}$, Chih-Chi Yang ${ }^{2} \mathbb{D}$, Ku-Fan Chen ${ }^{2} \mathbb{D}$ and Yung-Pin Tsai ${ }^{2, *(\mathbb{C}}$ \\ 1 Department of Health and Applied Sciences, Dong Nai Technology University, Bien Hoa, \\ Dong Nai 810000, Vietnam; daokhanhchau07@gmail.com \\ 2 Department of Civil Engineering, National Chi Nan University, Nantou Hsien 54561, Taiwan; \\ chi813@gmail.com (C.-C.Y.); kfchen@ncnu.edu.tw (K.-F.C.) \\ * Correspondence: yptsai@ncnu.edu.tw; Tel.: +886-49-2910960 (ext. 4121)
}

Received: 4 March 2020; Accepted: 30 March 2020; Published: 7 April 2020

\begin{abstract}
Due to various potential toxicological threats to living organisms even at low concentrations, pharmaceuticals and personal care products in natural water are seen as an emerging environmental issue. The low efficiency of removal of pharmaceuticals and personal care products by conventional wastewater treatment plants calls for more efficient technology. Research on advanced oxidation processes has recently become a hot topic as it has been shown that these technologies can effectively oxidize most organic contaminants to inorganic carbon through mineralization. Among the advanced oxidation processes, the electrochemical advanced oxidation processes and, in general, electrochemical oxidation or anodic oxidation have shown good prospects at the lab-scale for the elimination of contamination caused by the presence of residual pharmaceuticals and personal care products in aqueous systems. This paper reviewed the effectiveness of electrochemical oxidation in removing pharmaceuticals and personal care products from liquid solutions, alone or in combination with other treatment processes, in the last 10 years. Reactor designs and configurations, electrode materials, operational factors (initial concentration, supporting electrolytes, current density, temperature, $\mathrm{pH}$, stirring rate, electrode spacing, and fluid velocity) were also investigated.
\end{abstract}

Keywords: advanced oxidation processes; electrochemical advanced oxidation processes; pharmaceuticals and personal care products; electrochemical oxidation; anodic oxidation

\section{Introduction}

The concern for pharmaceuticals and personal care products (PPCPs) as toxic substances in the environment and the essential to assess their environmental risks have significantly increased recently. PPCPs are defined as a group of compounds that is including pharmaceutical drugs, cosmetic ingredients, food supplements, and ingredients in other consumer products (e.g., shampoos, lotions) [1]. Pharmaceuticals are used to prevent or treat diseases on humans and animals, whereas personal care products (PCPs) are used mostly to improve the quality of daily life [2]. They are considered as emerging pollutants (new products or chemicals without regulatory status) and whose effects on the environment and human health are unidentified [3]. Due to the widespread occurrence in water bodies, regardless of the low concentrations (normally ranging from $\mathrm{ng} / \mathrm{L}$ to $\mu \mathrm{g} / \mathrm{L}$ ), residues of PPCP can harm human and animal health when it enters and accumulates in the food chain, causing unknown long-term effects $[2,4]$.

During wastewater treatment (WWT) processes, many PPCPs experience microbial mediated reactions [5] in the environment. Thus, transformation products are formed. The transformation 
of PPCPs can occur during WWT, depending on the compound's physicochemical properties and conditions, where PPCPs can be destroyed or partially transformed or remained unchanged [6]. In this review, it can be seen that the effect of PPCPs in the environment does not only depend on concentration but also persistence, bioaccumulation, biotransformation, and elimination. Some PPCPs produce metabolites or by-products more harmful than the parent compounds. Toxicity evaluation is an important environmental pollution control factor since the degradation by-products from the initial structure can be more toxic.

Biodegradation, photodegradation, and other processes of abiotic transformation, such as hydrolysis [7], can reduce environmental concentrations of PPCPs and result in partial loss and mineralization of these compounds. Chiron et al. [8] revealed that acridine is a photodegradation product of carbamazepine under artificial estuarine water conditions, whereas tetracycline could not be photodegraded due to its sediment adsorption [9].

The electrochemical oxidation process (EOP) can be described as an electrochemical technology capable of achieving oxidation of contaminants from water or wastewater, either by direct or mediated oxidation processes originating on the anode surface of the electrochemical cell. This means that these oxidative processes should not actually be carried out on the anode, but only on its surface. As a consequence, this technique incorporates two main types of processes [10]: heterogeneous and homogeneous oxidation. Direct anodic oxidation or electrolysis occurs directly on the anode (M) with direct charge transfer reactions between the surface of the anode and the organic contaminants involved. The mechanism requires only the mediation of electrons that are capable of oxidizing such organic compounds at defined potentials more negative the oxygen evolution potential [11]. The indirect electrochemical oxidation by reactive oxygen species is based on the electro-generation of adsorbed ${ }^{*} \mathrm{OH}\left(\mathrm{E}^{\circ}=2.8 \mathrm{~V} / \mathrm{SHE}\right)$ onto the anode surface as an intermediate of the OEP $[10,12]$.

This paper intends to be a powerful tool for researchers in the pursuit of comprehensive information on the removal of PPCPs from liquid solutions by EOP, alone or in combination with other treatment processes. The remediation of aqueous or real wastewater was assessed, regarding many features like the configuration of the electrochemical reactor, anode and cathode characteristics, and operational parameters such as initial PPCPs concentration, supporting electrolytes, current density (j), temperature, $\mathrm{pH}$, temperature, stirring rate, electrode spacing, and fluid velocity.

\section{Origins and Classification of PPCPs}

Direct and indirect pathways can introduce PPCPs into the environment. PPCPs may enter surface water by direct discharge into surface water from factories, hospitals, households, and WWTPs, as well as through land runoff in the case of biosolids distributed over agricultural land that may touch groundwater by leaching or bank filtration. Sediment can adsorb PPCPs within the surface water compartment because of various binding sites [13]. Soil may also be one of the PPCPs sinks. PPCPs can pass through irrigation into the soil with PPCPs containing treated and untreated wastewater. These can also be moved to the soil through an atmospheric wet deposition for some PPCPs [14].

Wastewater, including domestic, municipal, and hospital wastewater, are the primary sources that bring pharmaceuticals into the environment (both point- and nonpoint-sources) from various activities such as wastes (human and animal), landfill leachate, biosolid, and direct disposal of pharmaceuticals. Such pharmaceuticals then can not be biodegradable ultimately in WWTPs and enter the receiving waters [15-17]. In WWTPs, activated sludge is the main process for secondary treatment which can remove various kinds of PPCPs from wastewater. However, the removal rate depends greatly on physiochemical characteristics, reactors applied, and operational conditions (hydraulic retention time, sludge retention time, and $\mathrm{pH}$ ) as well [18]. Table 1 summarizes the target PPCPs selected for this study and their structures, Table 2 updates the removal efficiency of PPCPs by combining biological treatment with other processes. 
Table 1. Structures, chemical abstracts service registry number (CAS), and classification for the target pharmaceuticals and personal care products (PPCPs) selected for this study.

\begin{tabular}{|c|c|c|c|}
\hline $\begin{array}{l}\text { Compounds } \\
\text { (CAS) } \\
\text { Classification }\end{array}$ & Structure & $\begin{array}{l}\text { Compounds } \\
\text { (CAS) } \\
\text { Classification }\end{array}$ & Structure \\
\hline $\begin{array}{c}\text { Aspirin } \\
(50-78-2) \\
\text { Nonsteroidal anti-inflammatory } \\
\text { drugs (NSAIDs) }\end{array}$ & & $\begin{array}{l}\text { Lamivudine } \\
(134678-17-4) \\
\text { Antivirals }\end{array}$ & \\
\hline $\begin{array}{c}\text { Atenolol } \\
(29122-68-7) \\
\text { Beta-blockers }\end{array}$ & & $\begin{array}{c}\text { Levodopa } \\
(59-92-7) \\
\text { Antiparkinson Agents }\end{array}$ & $\mathrm{H}$ \\
\hline $\begin{array}{l}\text { Berberine } \\
(2086-83-1) \\
\text { Antibiotics }\end{array}$ & & $\begin{array}{c}\text { Methotrexate } \\
\quad(59-05-2) \\
\text { Antineoplastics }\end{array}$ & \\
\hline $\begin{array}{l}\text { Caffeine } \\
(58-08-2) \\
\text { Stimulant }\end{array}$ & $\mathrm{CH}_{3}$ & $\begin{array}{l}\text { Metronidazole } \\
(443-48-1) \\
\text { Antibiotics }\end{array}$ & \\
\hline $\begin{array}{l}\text { Carbamazepine } \\
\quad(298-46-4) \\
\text { Anticonvulsants }\end{array}$ & $\mathrm{N}$ & $\begin{array}{l}\text { Musk ketone } \\
\quad(81-14-1) \\
\text { Fragrances }\end{array}$ & $\underset{\mathrm{CH}_{3}}{\mathrm{H}}$ \\
\hline
\end{tabular}


Table 1. Cont.

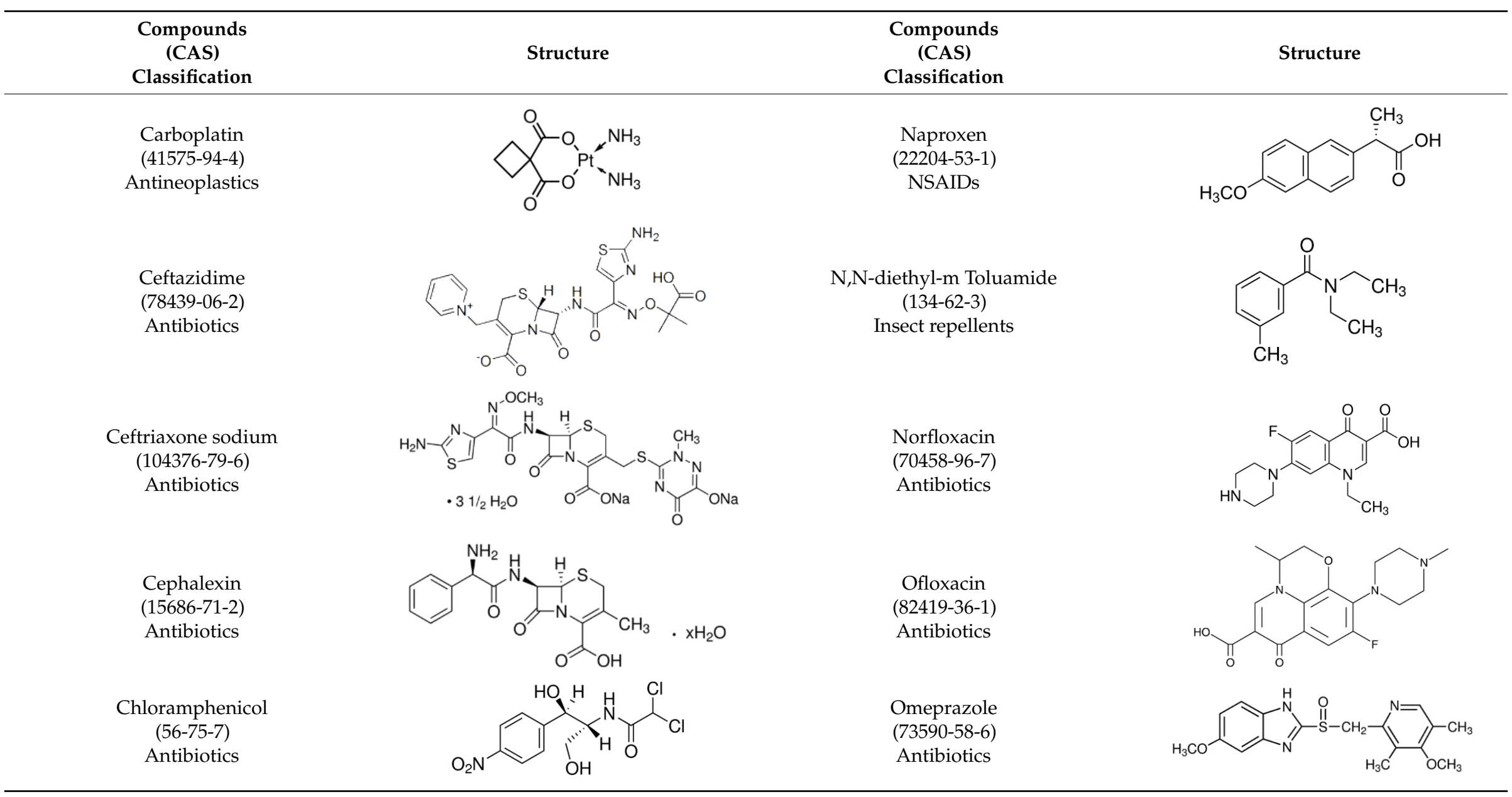


Table 1. Cont.

\begin{tabular}{|c|c|c|c|}
\hline $\begin{array}{l}\text { Compounds } \\
\text { (CAS) } \\
\text { Classification }\end{array}$ & Structure & $\begin{array}{l}\text { Compounds } \\
\text { (CAS) } \\
\text { Classification }\end{array}$ & Structure \\
\hline $\begin{array}{c}\text { Ciprofloxacin } \\
(85721-33-1) \\
\text { Antibiotics }\end{array}$ & & $\begin{array}{c}\text { Methyl Paraben } \\
(99-76-3) \\
\text { Preservatives }\end{array}$ & \\
\hline $\begin{array}{c}\text { Clofibric acid } \\
(882-09-7) \\
\text { Blood lipid regulators }\end{array}$ & & $\begin{array}{l}\text { Paracetamol } \\
(103-90-2) \\
\text { NSAIDs }\end{array}$ & \\
\hline $\begin{array}{l}\text { Diclofenac } \\
(15307-86-5) \\
\text { NSAIDs }\end{array}$ & & $\begin{array}{l}\text { Rifampicin } \\
(13292-46-1) \\
\text { Antibiotics }\end{array}$ & \\
\hline $\begin{array}{c}\text { Enrofloxacin } \\
(93106-60-6) \\
\text { Antibiotics }\end{array}$ & & $\begin{array}{c}\text { Salicylic acid } \\
\quad(69-72-7) \\
\text { NSAIDs }\end{array}$ & \\
\hline $\begin{array}{l}\text { Estrone } \\
(53-16-7) \\
\text { Hormones }\end{array}$ & & $\begin{array}{c}\text { Sulfamethoxazole } \\
(723-46-6) \\
\text { Antibiotics }\end{array}$ & \\
\hline
\end{tabular}


Table 1. Cont

\begin{tabular}{|c|c|c|c|}
\hline $\begin{array}{l}\text { Compounds } \\
\text { (CAS) } \\
\text { Classification }\end{array}$ & Structure & $\begin{array}{l}\text { Compounds } \\
\text { (CAS) } \\
\text { Classification }\end{array}$ & Structure \\
\hline $\begin{array}{l}\text { Ibuprofen } \\
(15687-27-1) \\
\text { NSAIDs }\end{array}$ & & $\begin{array}{c}\text { Sulfachloropyrida-zine } \\
(80-32-0) \\
\text { Antibiotics }\end{array}$ & \\
\hline $\begin{array}{c}\text { Iohexol } \\
(66108-95-0) \\
\text { Radiological Non-Ionic } \\
\text { Contrast Media }\end{array}$ & & $\begin{array}{l}\text { Sulfadiazine } \\
\text { (68-35-9) } \\
\text { Antibiotics }\end{array}$ & \\
\hline $\begin{array}{c}\text { 2-methyl-4-isothiazolin-3-one } \\
\text { (2682-20-4) } \\
\text { Preservatives }\end{array}$ & & $\begin{array}{c}\text { Tetracycline } \\
(60-54-8) \\
\text { Antibiotics }\end{array}$ & \\
\hline $\begin{array}{l}\text { Ketoprofen } \\
(22071-15-4) \\
\text { NSAIDs }\end{array}$ & & & \\
\hline
\end{tabular}


Table 2. The removal efficiency of PPCPs by combining biological treatment with other processes.

\begin{tabular}{|c|c|c|c|c|}
\hline Compounds & Initial Concentration & Treatment Processes & Removal Efficiency (\%) & Ref. \\
\hline \multirow[t]{2}{*}{ Aspirin } & $930 \mathrm{ng} / \mathrm{L}$ & Modified Bardenpho process & 92 & [19] \\
\hline & $255 \mathrm{ng} / \mathrm{L}$ & Grit tanks|primary sedimentation|bioreactor|clarifiers & 47.1 & [19] \\
\hline \multirow[t]{2}{*}{ Atenolol } & $1197 \mathrm{ng} / \mathrm{L}$ & Pretreatment|primary (settling)|secondary activated sludge (AS) & 14.4 & [20] \\
\hline & $2.3 \pm 2.0$ & Grit removal|primary clarifier|denitrification|nitrification|second clarifier & 84 & [21] \\
\hline Berberine & $75.0-375.0 \mathrm{mg} / \mathrm{L}$ & Upflow anaerobic sludge blanket (UASB)-membrane bioreactor (MBR) & 99 & [22] \\
\hline \multirow{2}{*}{ Caffeine } & $82 \pm 36 \mu \mathrm{g} / \mathrm{L}$ & Grit removal|primary clarifier|denitrification|nitrification|second clarifier & 99.7 & {$[21]$} \\
\hline & $22,849 \mathrm{ng} / \mathrm{L}$ & Anaerobic/Anoxic/Oxic (A2O) & 94.9 & [23] \\
\hline \multirow{3}{*}{ Carbamazepine } & $208-416 \mathrm{ng} / \mathrm{L}$ & A series of different waste stabilization ponds & 73 & [24] \\
\hline & $129 \mathrm{ng} / \mathrm{L}$ & Pretreatment|primary (settling)|secondary AS & 9.5 & {$[20]$} \\
\hline & $2.0 \pm 1.3 \mu \mathrm{g} / \mathrm{L}$ & Grit removal|primary clarifier|denitrification|nitrification|second clarifier & 0 & [21] \\
\hline Carboplatin & 4.7 to $145 \mu \mathrm{g} / \mathrm{L}$ & Adsorption to AS & $70 \%$ & [25] \\
\hline Ceftazidime & $40 \mathrm{mg} / \mathrm{L}$ & Coupling ultraviolet (UV)|algae-algae treatment & 97.26 & [26] \\
\hline Ceftriaxone & $14 \mu \mathrm{g} / \mathrm{L}$ & AS process & $<1$ & [27] \\
\hline Cephalexin & $4.6 \mathrm{mg} / \mathrm{L}$ & Grit channels|primary clarifies|conventional AS|Final settling & 87 & {$[28]$} \\
\hline \multirow{2}{*}{ Chloramphenicol } & $206 \pm 56 \mathrm{ng} / \mathrm{L}$ & Preliminary screening|primary sedimentation|conventional AS treatment & $>70$ & [29] \\
\hline & $31 \pm 16 \mathrm{ng} / \mathrm{L}$ & Screen|primary clarifier|AS system for denitrification and nitrification & 50 & [30] \\
\hline \multirow{2}{*}{ Ciprofloxacin } & $2200 \mathrm{ng} / \mathrm{L}$ & Grit channels|primary clarifies|conventional AS & -88.6 & {$[31]$} \\
\hline & $5524 \mathrm{ng} / \mathrm{L}$ & Pretreatment|primary (settling)|secondary AS & 57 & [20] \\
\hline \multirow{3}{*}{ Clofibric acid } & $2 \mathrm{mg} / \mathrm{L}$ & Aerobic sequencing batch reactors (SBRs) with mixed microbial cultures & 51 & [32] \\
\hline & $0.25 \pm 0.09 \mu \mathrm{g} / \mathrm{L}$ & Grit removal|primary clarifier|denitrification|nitrification|second clarifier & 52 & [21] \\
\hline & $26 \mathrm{ng} / \mathrm{L}$ & Pretreatment|primary (settling)|secondary AS & 54.2 & {$[20]$} \\
\hline \multirow{3}{*}{ Diclofenac } & $20-70 \mathrm{mg} / \mathrm{L}$ & Primary treatment|Orbal oxidation ditch|UV disinfection & $10-60$ & {$[33]$} \\
\hline & $2.0 \pm 1.5 \mu \mathrm{g} / \mathrm{L}$ & Grit removal|primary clarifier|denitrification|nitrification|second clarifier & 96 & [21] \\
\hline & $232 \mathrm{ng} / \mathrm{L}$ & Pretreatment|primary (settling)|secondary AS & 5 & {$[20]$} \\
\hline Enrofloxacin & $9-170 \mathrm{ng} / \mathrm{L}$ & Conventional AS|UV disinfection & 65 & [34] \\
\hline \multirow[t]{2}{*}{ Estrone } & $57 \mathrm{ng} / \mathrm{L}$ & Grit channels|primary clarifies|conventional AS & 93.7 & [31] \\
\hline & $4500 \mathrm{ng} / \mathrm{L}$ & Grit channels|primary clarifies|conventional AS & 99.7 & [31] \\
\hline \multirow[t]{2}{*}{ Ibuprofen } & $3.4 \pm 1.7 \mu \mathrm{g} / \mathrm{L}$ & Grit removal|primary clarifier|denitrification|nitrification|second clarifier & 96 & [21] \\
\hline & $2687 \mathrm{ng} / \mathrm{L}$ & Pretreatment|primary (settling)|secondary AS & 95 & {$[20]$} \\
\hline Iohexol & $9.0 \pm 2.0 \mu \mathrm{g} / \mathrm{L}$ & Grit removal|primary clarifier|denitrification|nitrification|second clarifier & 89 & [21] \\
\hline $\begin{array}{l}\text { 2-methyl-4-isothiazolin- } \\
\text { 3-one }\end{array}$ & $1-3 \mathrm{mg} / \mathrm{L}$ & Aerobic process & $80-100$ & {$[35]$} \\
\hline Ketoprofen & $441 \mathrm{ng} / \mathrm{L}$ & Anaerobic/Anoxic/Oxic (A2O) & 11.2 & [23] \\
\hline Lamivudine & $210 \pm 13 \mathrm{ng} / \mathrm{L}$ & Screen|aerated grit-removal|primary clarifier|nitrification/denitrification & $>76$ & {$[36]$} \\
\hline
\end{tabular}


Table 2. Cont

\begin{tabular}{|c|c|c|c|c|}
\hline Compounds & Initial Concentration & Treatment Processes & Removal Efficiency (\%) & Ref. \\
\hline Methotrexate & $7.30-55.8 \mathrm{ng} / \mathrm{L}$ & Pretreatment|primary (settling)|secondary AS & 100 & [20] \\
\hline Metronidazole & $90 \mathrm{ng} / \mathrm{L}$ & Anaerobic/Anoxic/Oxic (A2O) & 38.7 & [23] \\
\hline Musk ketone & $0.640 \pm 0.395 \mu \mathrm{g} / \mathrm{L}$ & Primary gravitational settling|AS & $91.0 \pm 5.2$ & [37] \\
\hline \multirow{2}{*}{ Naproxen } & $3000 \mathrm{ng} / \mathrm{L}$ & Grit channels|primary clarifies|conventional AS & 96.2 & [31] \\
\hline & $2363 \mathrm{ng} / \mathrm{L}$ & Pretreatment|primary (settling)|secondary AS & 60.9 & [20] \\
\hline DEET & $503 \mathrm{ng} / \mathrm{L}$ & Primary|secondary treatment with AS & $19.2-46.2$ & [38] \\
\hline Norfloxacin & $229 \pm 42 \mathrm{ng} / \mathrm{L}$ & Screen|primary clarifier|AS system for denitrification and nitrification & 66 & [30] \\
\hline \multirow{2}{*}{ Ofloxacin } & $2100 \mathrm{ng} / \mathrm{L}$ & Grit channels|primary clarifies|conventional AS & 124.2 & [31] \\
\hline & $2275 \mathrm{ng} / \mathrm{L}$ & Pretreatment|primary (settling)|secondary AS & 64.1 & [20] \\
\hline Omeprazole & $365 \mathrm{ng} / \mathrm{L}$ & Pretreatment|primary (settling)|secondary AS & 8.5 & [20] \\
\hline Methyl Paraben & $801 \mathrm{ng} / \mathrm{L}$ & Conventional biological treatment with $\mathrm{P}$ and $\mathrm{N}$ removal & 100 & [39] \\
\hline \multirow{2}{*}{ Paracetamol } & $218,000 \mathrm{ng} / \mathrm{L}$ & Modified Bardenpho process & 99 & [19] \\
\hline & $23,202 \mathrm{ng} / \mathrm{L}$ & Pretreatment|primary (settling)|secondary AS & 100 & [20] \\
\hline Rifampicin & $0-31 \mathrm{ng} / \mathrm{L}$ & $\begin{array}{l}\text { Secondary treatment process: AS, biological filtration oxygenated reactor, } \\
\text { anoxic/oxic }(\mathrm{A} / \mathrm{O}) \text {, cyclic AS technology (CAST), and } \mathrm{A} 2 \mathrm{O}\end{array}$ & 0-100 & [40] \\
\hline \multirow[t]{2}{*}{ Salicylic acid } & $5.866 \mu \mathrm{g} / \mathrm{L}$ & Primary|secondary treatment: trickling filter beds|final clarification. & $>98$ & [41] \\
\hline & $7400 \mathrm{ng} / \mathrm{L}$ & Grit channels|primary clarifies|conventional AS & -35.8 & [31] \\
\hline \multirow{3}{*}{ Sulfamethoxazole } & $0.82 \pm 0.23 \mu \mathrm{g} / \mathrm{L}$ & Grit removal|primary clarifier|denitrification|nitrification|second clarifier & 24 & [21] \\
\hline & $524 \mathrm{ng} / \mathrm{L}$ & Pretreatment|primary (settling)|secondary AS & 31.2 & [20] \\
\hline & $118 \pm 17 \mathrm{ng} / \mathrm{L}$ & Screen|primary clarifier|AS system for denitrification and nitrification & 64 & [30] \\
\hline Sulfachloropyridazine & $0.19 \mu \mathrm{g} / \mathrm{L}$ & Conventional AS & 62 & [42] \\
\hline Sulfadiazine & $72 \pm 22 \mathrm{ng} / \mathrm{L}$ & Screen|primary clarifier|AS system for denitrification and nitrification & 50 & [30] \\
\hline Tetracycline & $257 \pm 176 \mathrm{ng} / \mathrm{L}$ & Preliminary screening|primary sedimentation|conventional AS treatment & 69 & [29] \\
\hline
\end{tabular}




\section{Analytical Methods of PPCPs}

Figure 1 shows the analytical method that is essential to investigate the occurrence of PPCPs in the environment, whichs consists of several main steps. This includes selecting appropriate analytical instruments (Table 3), which depend on the characteristics of PPCPs; extracting and purifying the samples by using techniques such as solid-phase extraction (SPE), liquid-liquid extraction (LLE), liquid-liquid micro-extraction (LLME), and solid-phase micro-extraction (SPME) that was introduced in various studies [43,44]; and optimizing of measurement parameters.

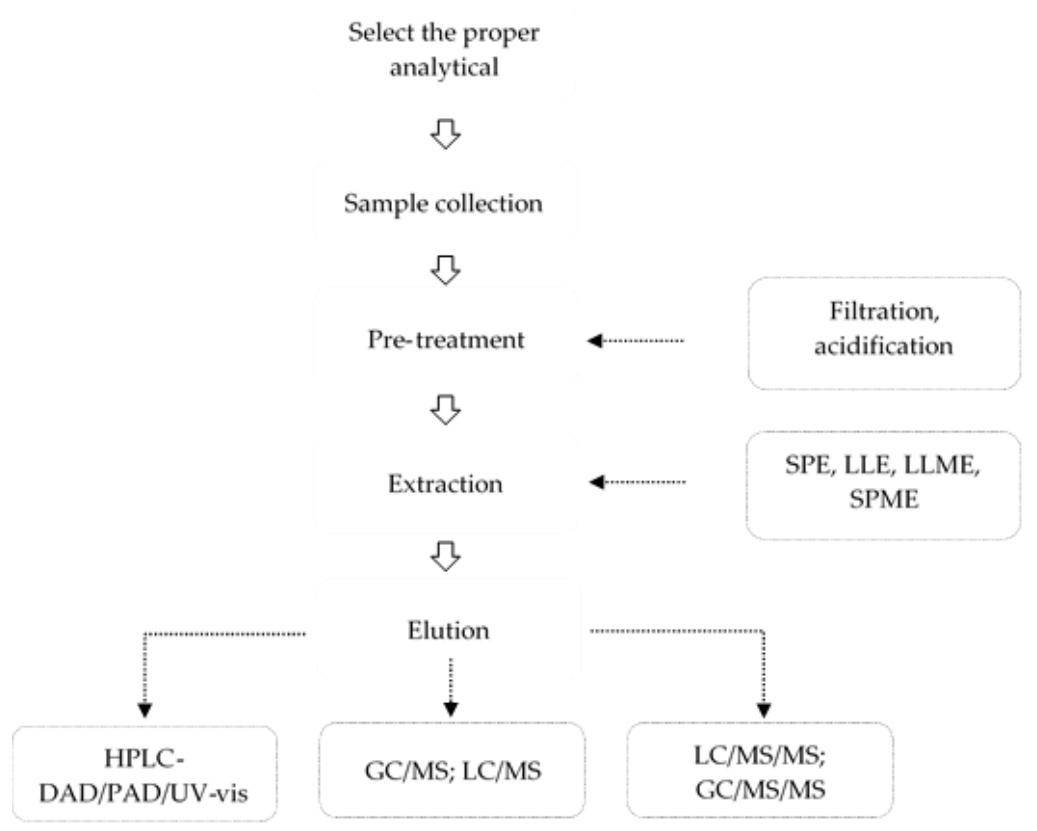

Figure 1. PPCPs analytical method procedure. Solid-phase extraction: SPE; liquid-liquid extraction: LLE; liquid-liquid micro-extraction: LLME; solid-phase micro-extraction: SPME; HPLC: High-performance liquid chromatography; DAD: Diode array detector; PAD: photodiode detector; UV-vis: ultraviolet-visible detector; GC/MS: Gas chromatography-mass spectrometry; LC/MS: Liquid chromatography-mass spectrometry.

Table 3. The analytical methods of PPCPs in the literature.

\begin{tabular}{ll}
\hline \multicolumn{1}{c}{ Analytical Methods } & \multicolumn{1}{c}{ PPCPs } \\
\hline GC-MS & Ciprofloxacin, Chloramphenicol, Methyl paraben \\
\hline \multirow{2}{*}{ HPLC } & Lamivudine, Ceftazidime, Carboplatin, Aspirin, Cephalexin, \\
& Musk ketone, Norfloxacin, Ceftriaxone sodium, Levodopa, \\
& N,N-diethyl-m-Toluamide (DEET) \\
\hline \multirow{2}{*}{ HPLC-DAD } & Acetaminophen, Diclofenac, Sulfamethoxazole, \\
& Chloramphenicol, Ofloxacin, Berberine, Tetracycline \\
\hline \multirow{3}{*}{ HPLC-UV/HPLC-UV vis/UV-vis } & $\begin{array}{l}\text { Ciprofloxacin, Rifampicin, Carbamazepine, Caffeine, } \\
\text { Enrofloxacin, Sulfamethoxazole, Diclofenac, }\end{array}$ \\
& Isothdiazolin-3-ones, Metronidazole, Estrone, Paracetamol, \\
& Diclofenac, Methyl paraben, Clofibric acid, Sulfonamides \\
\hline \multirow{2}{*}{ HPLC-HR-MS/HPLC-MS/HPLC-MS-MS } & $\begin{array}{l}\text { Carbamazepine, Iohexol, Ceftazidime, Methotrexate, Ibuprofen, } \\
\text { Clofibric acid }\end{array}$ \\
\hline \multirow{2}{*}{ HPLC-PDA } & Atenolol, Paracetamol, Salicylic acid, Parabens, \\
& Sulfachloropyridazine, Omeprazole, Ibuprofen, Naproxen, \\
& Carbamazepine \\
\hline
\end{tabular}




\section{Removal of PPCPs from Liquid Solutions by EOP}

\subsection{Electrochemical Reactor Designs and Configurations}

There are two types of electrodes: two-dimensional and three-dimensional. Compared to two-dimensional, three-dimensional electrodes ensures a high electrode surface-to-cell volume ratio value. Due to the ease of scale up to a larger electrode size, more electrode pairs, or an increased number of cell stacks, cell designs using the parallel plate geometry in a filter press arrangement are widely used [45].

In the configuration of the reactor, the cell arrangement (divided and undivided cells) must be considered. The anolyte and catholyte are separated into divided cells by a porous diaphragm or ion-conducting membrane. Choosing the separating diaphragm or membrane is as critical for divided cells as choosing the correct electrode materials for proper electrolyte system functioning. Generally, the use of divided cells should be avoided wherever possible regarding the cost of separators, the complexity of reducing the electrode gap and the problems of the mechanic, and corrosion [46]. Undivided cells working in batch mode are often under magnetic stirring for mixing at a thermostatically controlled temperature (Figure 2). The number of electrodes can increase the active area per volume unit.

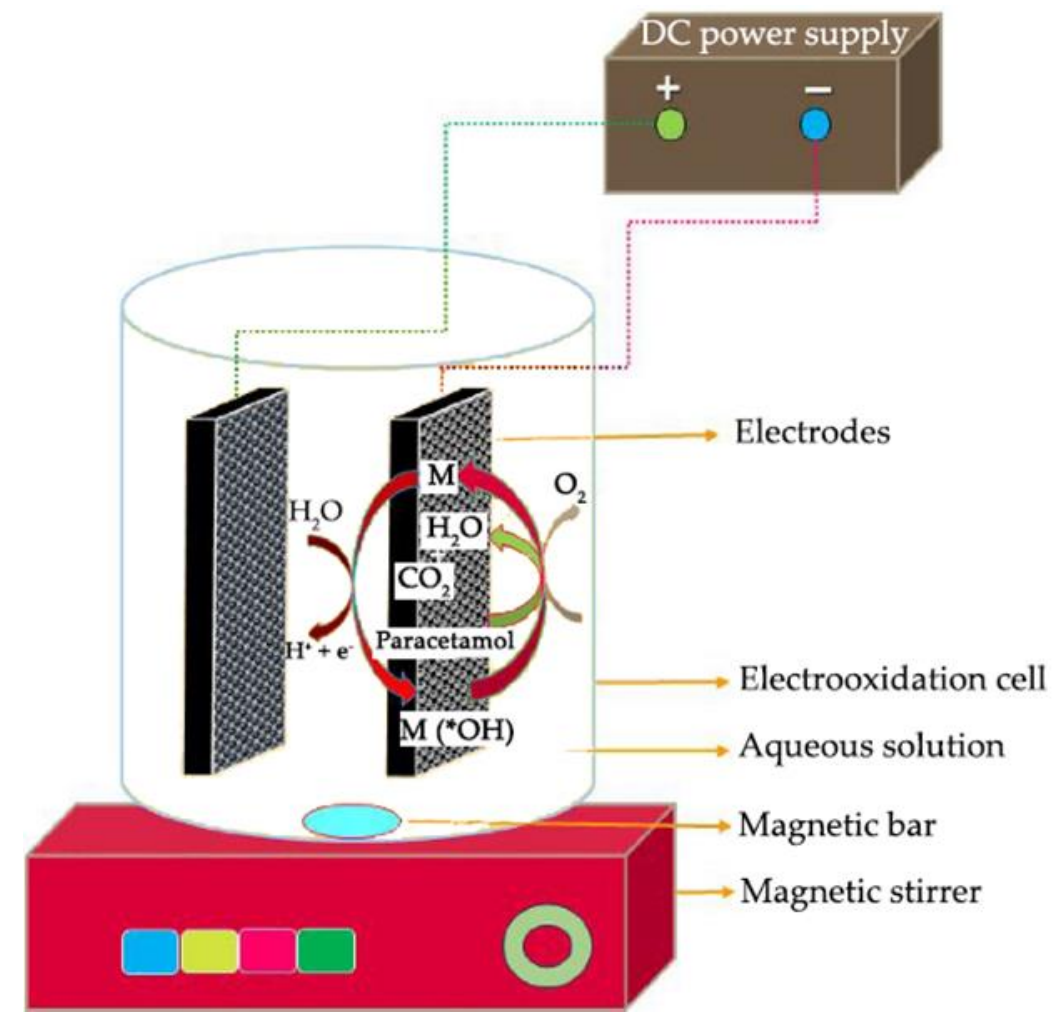

Figure 2. Diagram of the electrochemical reactor, using a glass beaker. The solution was stirred continuously throughout the process with a magnetic bar on a magnetic stirrer. The graphite anode was used as a working anode and a distance of $2 \mathrm{~mm}$. Reprinted from Periyasamy and Muthuchamy [47], copyright (C) (2018) with permission from Elsevier.

Most of the studies were conducted in undivided electrochemical reactors, usually using solution volumes ranging from 100 to $500 \mathrm{~mL}$, although $1 \mathrm{~L}$ or larger volumes were sometimes used [48-50]. Divided cells use a separator between anolyte and catholyte, which makes the treatment process more costly and challenging due to the penalty overvoltage of the separator. The investigation of norfloxacin degradation in an electrochemical reactor with the presence and absence of an ion-exchange membrane proved the use of the membrane is highly advantageous as it enhances the anodic reaction kinetics and improves the current efficiency. This leads to an improvement in the degradation of norfloxacin, 
mineralization, and the consequent mineralization current efficiency [51]. Moreover, Chen et al. [52] used successfully divided and thermostated cells and a Nafion 212 ion-exchange membrane separator to perform electrodegradation of DEET with total removal.

Since the metal deposition occurs on the surface of the cathode to boost the space-time yield, it is required to increase the surface area. Therefore, the fluidized bed electrode was developed, with granular graphite and glass beads for filling the gap between the main electrodes and used as the third electrode [32].

Filter-press cells have been used by coupling to a pump and a reservoir (Figure 3). One module including an anode, a cathode, and a membrane (if necessary) makes it relatively easy to operate and maintain the reactor.

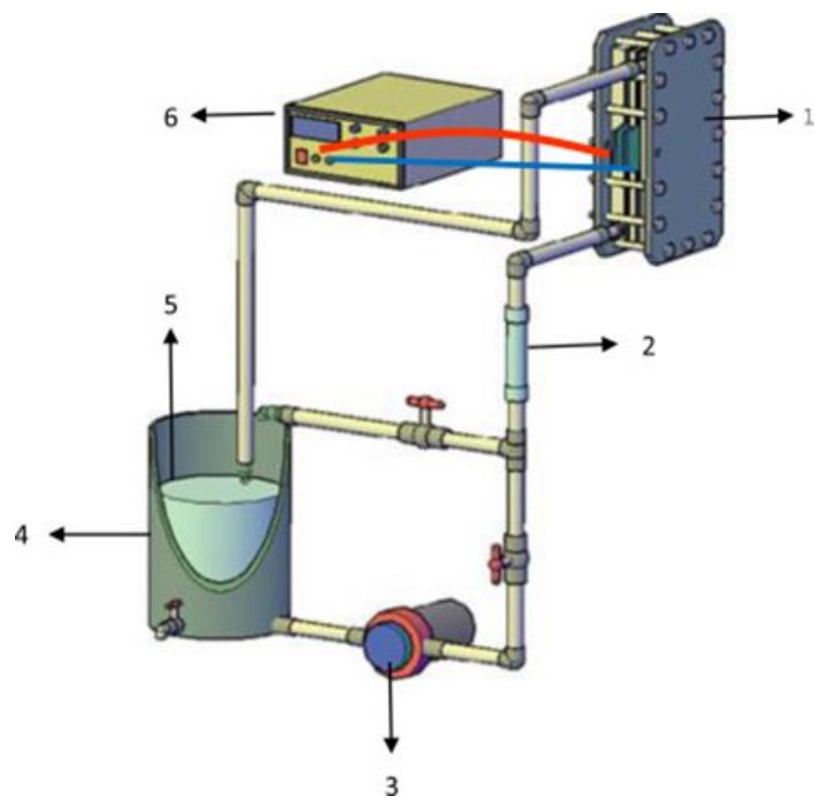

Figure 3. Experimental setup of $4 \mathrm{~L}$ undivided filter flow press reactor used for the treatment of paracetamol and diclofenac. 1. flow electrolytic cell, 2. flow meter, 3. peristaltic pump, 4. reservoir, 5. sampling, and 6. power supply. Reprinted from García-Montoya et al. [50], copyright (C) (2015), with permission from Elsevier.

\subsection{Electrode Materials}

It has also been shown that the anodes with high over-potential $\mathrm{O}_{2}$ yield better electrochemical oxidation results [53-56]. Consequently, the electrode material $(\mathrm{M})$ has a significant impact on the performance of PPCPs in oxidative degradation. Accordingly, an interesting issue is a systematic research on the comparative performance of electrode materials.

Sopaj et al. [57] tested on different electrode materials such as carbon felt, carbon fiber, carbon graphite, Platinum (Pt), lead dioxide, dimensionally stable anode (DSA) [58], ( $\mathrm{Ti} / \mathrm{RuO}_{2}-\mathrm{IrO}_{2}$ ), and boron-doped diamond (BDD) for removing of amoxicillin in aqueous media. BDD anode was more effective in oxidizing and mineralizing amoxicillin in water than the DSA. Moreover, it can be obtained very high electrolysis efficiency for the BDD electrode during the initial stage, even for high current densities.

Barışçı et al. [59] showed the performance of electrodes was significantly different for the anti-cancer drug carboplatin degradation with various mixed metal oxide (MMO) electrodes and BDD electrode (Figure 4). CV voltammograms unveiled that $\mathrm{BDD}$, $\mathrm{Ti} / \mathrm{IrO}_{2}-\mathrm{RuO}_{2}, \mathrm{Ti} / \mathrm{RuO}_{2}$, and $\mathrm{Ti} / \mathrm{IrO}_{2}-\mathrm{Ta}_{2} \mathrm{O}_{5}$ anodes had the highest levels of oxygen evolution and the poorest anodes were $\mathrm{SnO}_{2} / \mathrm{Pt}, \mathrm{Ti} / \mathrm{Pt}$ and $\mathrm{Ti} / \mathrm{Ta}_{2} \mathrm{O}_{5}-\mathrm{SnO}_{2}-\mathrm{IrO}_{2}$. Besides, higher oxygen evolution overpotential explained the formation of $\mathrm{OH}^{*}$ on the surface of anode instead of molecular oxygen, which improved the efficiency. 


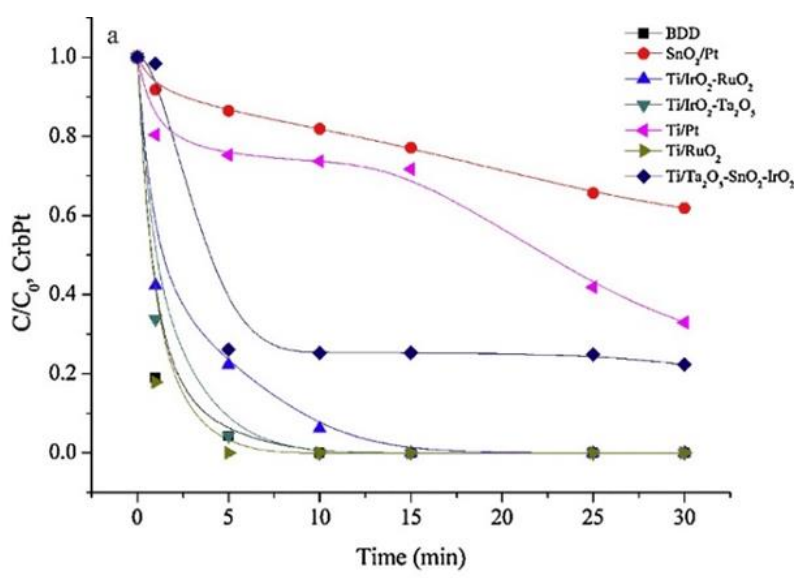

Figure 4. The effect of electrode material on anti-cancer drug carboplatin degradation under conditions: supporting electrolyte, $200 \mathrm{mg} / \mathrm{L} \mathrm{Na}_{2} \mathrm{SO}_{4} ; \mathrm{pH} 7$; current density, $30 \mathrm{~mA} \mathrm{~cm}{ }^{-2}$. Reprinted from Barışçı et al. [59], copyright (C) (2018), with permission from Elsevier.

\subsubsection{Lead and Lead Dioxide}

Because of the stability, low cost, and high oxygen evolution potential, lead and lead dioxide have been used as anode materials [60] (Table 4). Recent studies have paid considerable efforts to improve the performance, including the addition of a new intermediate layer between the substrate and the oxidation layer, doping metal, or non-metallic ions and the adoption of new preparation methods [61,62].

Dai et al. [55] found the catalytic effect of $\mathrm{La}-\mathrm{Gd}-\mathrm{PbO}_{2}$ showed the highest performance followed by that of $\mathrm{La}-\mathrm{PbO}_{2}, \mathrm{Gd}-\mathrm{PbO}_{2}, \mathrm{PbO}_{2}$, respectively, in levodopa degradation. Moreover, compared to the pure $\mathrm{PbO}_{2}$ electrode, the $\mathrm{PbO}_{2}$ electrode with $1 \%$ Mo had a higher oxygen evolution potential and higher current of reduction and oxidation peaks, which led to increasing in electrochemical activity and decreasing of energy consumption [63].

Porous Ti plays an essential role in improving lead dioxide electrode performance compared to the traditional planar Ti substrate. Zhao et al. [64] found that compared to the traditional $\mathrm{PbO}_{2}$ electrode, $\mathrm{Ti} / \mathrm{SnO}_{2}-\mathrm{Sb}_{2} \mathrm{O}_{3} / \mathrm{PbO}_{2}$ had higher stability, safety, and removal performance of musk ketone. Xie et al. [65] developed a $\mathrm{TiO}_{2}$-based $\mathrm{SnO}_{2}$ - $\mathrm{Sb}$ /polytetrafluoroethylene resin- $\mathrm{PbO}_{2}$ electrode based on $\mathrm{TiO}_{2}$ nanotubes and demonstrated the growing of $\mathrm{TiO}_{2}$ nanotubes on Ti material led to an increase in current efficiency. Before electrons flow, the electrode needs a large overpotential that minimizes the oxygen evolution, decreases the production of hydrogen peroxide and ozone, and favors the creation of ${ }^{*} \mathrm{OH}$, with the electron efficiency of $88.45 \%$. The degradation of ibuprofen demonstrated the degradation rate constant over $\mathrm{Ti} / \mathrm{SnO}_{2}-\mathrm{Sb} / \mathrm{Ce}-\mathrm{PbO}_{2}$ was two times of the value over $\mathrm{Ti} / \mathrm{Ce}-\mathrm{PbO}{ }_{2}[66]$.

\subsubsection{DSA}

In recent decades, MMO electrodes, known as DSA, have been made commercially available (Table 5). These consist of the corrosion-resistant base material, such as titanium or tantalum, coated with a metal oxide layer. DSA is catalytic oxide electrodes that, due to their low $\mathrm{Cl}_{2}$ overpotential, can effectively produce active chlorine species [67].

Studies verify the performance of three-dimensional (3D) was much better, more cost-effective, and saved more energy than traditional two-dimensional (2D). The highest efficiency was recorded in the $3 \mathrm{D}$ process for removing carbamazepine compared to a 2D electrochemical process [68]. Furthermore, using a 3D electrode reactor to treat estriol, in batch mode, exhibited reaction rate per unit area was significantly higher and lower energy consumption than conventional 2D electrode reactor with indirect oxidation as the main contributor to the degradation in the batch 3D electrode reactor at all electrode distances [69]. Over $80 \%$ of the removal efficiency was attributed to indirect oxidation at an electrode distance of $2 \mathrm{~cm}$ (Figure 5). 
Table 4. Selected results reported for PPCPs removal by electrochemical oxidation process (EOP) with lead and lead dioxide anodes.

\begin{tabular}{|c|c|c|c|c|c|c|c|c|c|c|}
\hline \multirow{2}{*}{ PPCPs } & \multirow{2}{*}{ Initial C } & \multirow{2}{*}{ Electrolyte } & \multirow{2}{*}{$\begin{array}{l}\mathrm{j} / \mathrm{mA}^{-2} \\
\mathrm{~cm}^{-2}\end{array}$} & \multirow{2}{*}{$\begin{array}{c}\text { Reactors/Operational } \\
\text { Parameters }\end{array}$} & \multicolumn{2}{|c|}{ Electrodes } & \multirow{2}{*}{$\mathrm{pH}$} & \multirow{2}{*}{$\begin{array}{l}\text { Reaction } \\
\text { Time } \\
\text { (min) }\end{array}$} & \multirow{2}{*}{$\begin{array}{c}\text { Removal } \\
(\%)\end{array}$} & \multirow{2}{*}{ Ref } \\
\hline & & & & & Anode & Cathode & & & & \\
\hline Lamivudine & $5 \mathrm{mg} / \mathrm{L}$ & $\begin{array}{c}20 \mathrm{mM} \\
\mathrm{Na}_{2} \mathrm{SO}_{4}\end{array}$ & $\geq 10$ & $\begin{array}{c}\text { Undivided cell, V } 450 \mathrm{~mL} \text {, } \\
\text { current density (j) }(6-14 \mathrm{~mA} \\
\left.\mathrm{cm}^{-2}\right)\end{array}$ & $\begin{array}{l}\mathrm{Ti} / \mathrm{SnO}_{2^{-}} \\
\mathrm{Sb} / \mathrm{Ce}-\mathrm{PbO}_{2} \\
7 \mathrm{~cm} \times 10 \mathrm{~cm} \\
\times 1 \mathrm{~mm}\end{array}$ & $\begin{array}{l}\text { Stainless steel } \\
\text { (SS); } \\
7 \mathrm{~cm} \times 10 \mathrm{~cm} \times 1 \\
\mathrm{~mm} \text {, gap } 2 \mathrm{~cm}\end{array}$ & $3-11$ & 240 & 70 (TOC) & {$[70]$} \\
\hline Ciprofloxacin & $50 \mathrm{mg} / \mathrm{L}$ & $\begin{array}{l}0.1 \mathrm{~mol} / \mathrm{L} \\
\mathrm{Na}_{2} \mathrm{SO}_{4}\end{array}$ & 30 & $\begin{array}{l}\text { Filter-press flow reactor; } \mathrm{pH} \\
(3,7, \text { and } 10) \text {, flow rate }(\mathrm{qV}= \\
\left.2.5,4.5 \text {, and } 6.5 \mathrm{~L} \mathrm{~min}^{-1}\right), \mathrm{j} \\
(6.6,20 \text {, and } 30 \mathrm{~mA} \mathrm{~cm}-2) \\
\text { and } \mathrm{T}=10,25 \text {, and } 40^{\circ} \mathrm{C}\end{array}$ & $\begin{array}{l}\mathrm{Ti}-\mathrm{Pt} / \beta-\mathrm{PbO}_{2} \\
3.1 \mathrm{~cm} \times 2.0 \\
\mathrm{~cm}, 3.1 \mathrm{~cm} \times \\
2.7 \mathrm{~cm}\end{array}$ & AISI 304 SS plate & 10 & 120 & 100 & [71] \\
\hline Ofloxacin & $20 \mathrm{mg} / \mathrm{L}$ & $\mathrm{Na}_{2} \mathrm{SO}_{4}$ & 30 & $\begin{array}{l}\text { Differential column batch } \\
\text { reactor, fluid velocity: } 0.003 \\
\text { and } 0.048 \mathrm{~m} / \mathrm{s} \text {, detention time: } \\
10.3-0.54 \mathrm{~min} .\end{array}$ & $\begin{array}{c}\mathrm{TiO}_{2} \text {-based } \\
\mathrm{SnO}_{2} \text {-Sb/FR- } \\
\mathrm{PbO}_{2} \\
2 \mathrm{~cm} \times 5 \mathrm{~cm}\end{array}$ & $\begin{array}{c}\text { SS foil; } \\
\text { Same shape and } \\
\text { size, gap } 0.5 \text { and } \\
3 \mathrm{~cm}\end{array}$ & 6.25 & 90 & 99.00 & [65] \\
\hline Enrofloxacin & $10 \mathrm{mg} / \mathrm{L}$ & $\begin{array}{r}20 \mathrm{mM} \\
\mathrm{Na}_{2} \mathrm{SO}_{4}\end{array}$ & 8 & $\begin{array}{l}\text { Undivided electrolytic cell, V } \\
30 \mathrm{~mL}, \mathrm{j}\left(2-10 \mathrm{~mA} / \mathrm{cm}^{2}\right), \mathrm{pH} \\
(\sim 3-11)\end{array}$ & $\begin{array}{c}\mathrm{Ti} / \mathrm{SnO}_{2}-\mathrm{Sb} / \mathrm{La}- \\
\mathrm{PbO}_{2} \\
25 \mathrm{~cm}^{2}\end{array}$ & $\begin{array}{c}\mathrm{Ti} ; \\
\text { Same area; gap } 5 \\
\mathrm{~mm}\end{array}$ & $3-11$ & 30 & 95.1 (TOC) & [72] \\
\hline Musk ketone & $50 \mathrm{mg} / \mathrm{L}$ & $\begin{array}{c}0.06 \mathrm{~mol} / \mathrm{L} \\
\mathrm{Na}_{2} \mathrm{SO}_{4}\end{array}$ & 40 & $\begin{array}{c}\text { Cylindrical single } \\
\text { compartment cell, V } 100 \mathrm{ml}, \\
\text { stirring rate } 800 \mathrm{rmin}^{-1}, \mathrm{j} \\
\left(10-50 \mathrm{~mA} \mathrm{~cm}^{-2}\right), \mathrm{pH}(3-11)\end{array}$ & $\begin{array}{c}\mathrm{Ti} / \mathrm{SnO}_{2-} \\
\mathrm{Sb}_{2} \mathrm{O}_{3} / \mathrm{PbO}_{2} \\
1 \mathrm{~cm} \times 1 \mathrm{~cm}\end{array}$ & $\begin{array}{c}\text { Stainless copper } \\
\text { foil; } \\
(2 \mathrm{~cm} \times 2 \mathrm{~cm}) \\
\text { gap } 1.5 \mathrm{~cm}\end{array}$ & 7 & 120 & 99.93 & {$[64]$} \\
\hline Levodopa & $100 \mathrm{mg} / \mathrm{L}$ & $\begin{array}{l}0.1 \mathrm{~mol} / \mathrm{L} \\
\mathrm{Na}_{2} \mathrm{SO}_{4}\end{array}$ & 50 & $\begin{array}{l}\text { Electrochemical system, V } \\
250 \mathrm{~mL}, \mathrm{j}\left(15-70 \mathrm{~mA} \mathrm{~cm}^{-2}\right)\end{array}$ & $\begin{array}{l}\mathrm{La}-\mathrm{Gd}-\mathrm{PbO}_{2} \\
12 \mathrm{~cm} \times 2 \mathrm{~cm} \\
\text { thickness: } 1 \\
\mathrm{~mm}, 14 \mathrm{~cm}^{2}\end{array}$ & $\begin{array}{l}\text { Ti; } \\
\text { The same area; } \\
\text { gap } 4 \mathrm{~cm}\end{array}$ & 5.9 & 120 & 100.00 & [55] \\
\hline
\end{tabular}




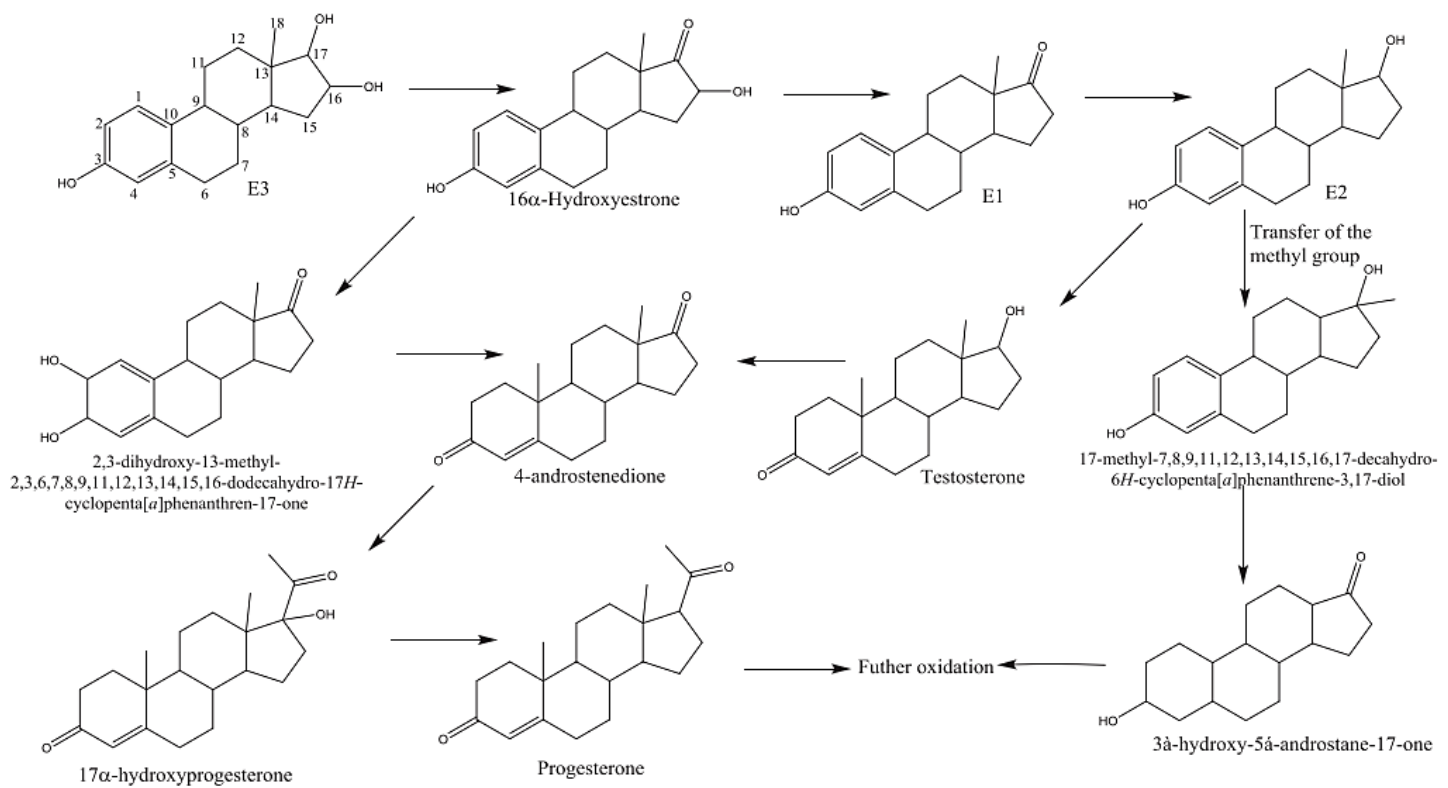

(a)

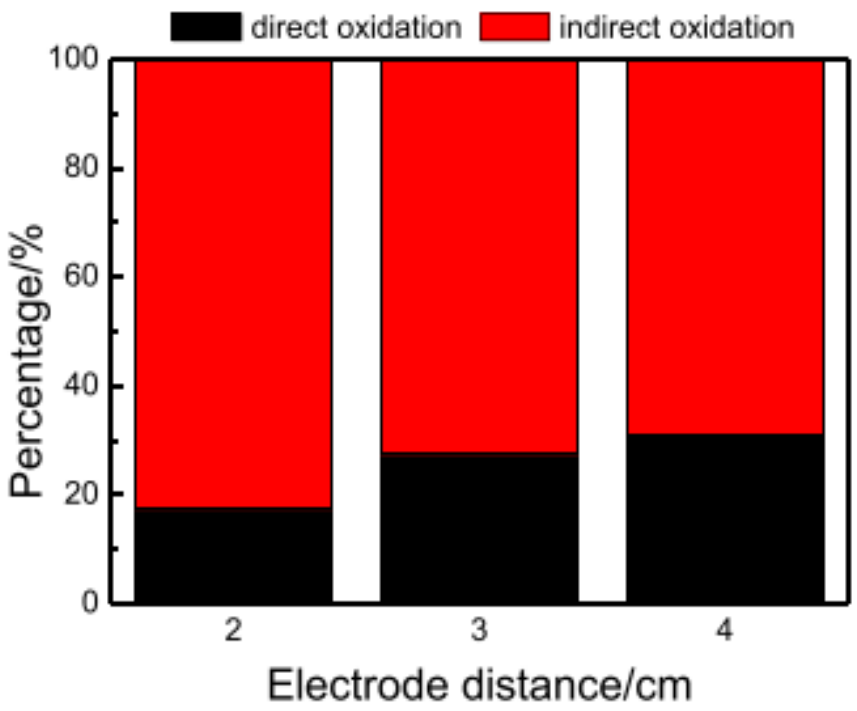

(b)

Figure 5. Proposed simplified pathways for estriol (E3) degradation in batch 3D electrolysis (a) and (b) the contribution of direct and indirect oxidation at various distances under operating conditions: $\mathrm{C}_{0}=$ approximately $1000 \mu \mathrm{g} / \mathrm{L}, \mathrm{j}=2.2 \mathrm{mAcm}^{-2}$, constant current, $\mathrm{Q}=150 \mathrm{~mL} / \mathrm{min}$. Reprinted from Shen et al. [69], copyright (C) (2017), with permission from Elsevier.

By adding powder activated carbon (PAC) or metal particles, the conductivity, mass transfer, or adsorption may also be increased in the 3D process [73]. The possibility of catalytic reaction and more reactive sites for adsorption are advantages of the 3D process that lead to better removal performance [74].

The $\mathrm{SnO}_{2}$ electrode has been widely used in wastewater treatment because of its high oxidation activity, it lower toxicity than $\mathrm{PbO}_{2}$, and it being more cost-effective than BDD. Sadly, it also contains limitations due to high energy consumption and instability. Adding $\mathrm{TiO}_{2}$ could reduce the electrode's internal passivation and charge transfer resistance, improving its stability and efficiency in oxidation when $\mathrm{Cu}$ limits the growth of crack morphology and offer more effective active sites. They accelerated 
electronic transfer and decreased $\mathrm{SnO}_{2}$ surface potential, improved the OEP, and increased the response current peak, which increased the electrode's oxidative degradation capacity [75]. Ti/SnO $\mathrm{S}_{2}-\mathrm{Cu}$ showed better stability and higher corrosion resistance than the conventional $\mathrm{Ti} / \mathrm{SnO}_{2}-\mathrm{Sb}$ electrode [76].

$\mathrm{RuO}_{2} / \mathrm{IrO}_{2}$-coated titanium anode with improved electrocatalytic behavior and stability are readily available in practical mesh geometries and have extended the lifetime and lower costs compared to BDD electrodes. Various DSA such as Ti/ $\mathrm{RuO}_{2}, \mathrm{Ti} / \mathrm{Pt}, \mathrm{Ti} / \mathrm{IrO}_{2}-\mathrm{RuO}_{2}, \mathrm{Ti} / \mathrm{IrO}_{2}-\mathrm{Ta}_{2} \mathrm{O}_{5}, \mathrm{Ti} / \mathrm{Ta}_{2} \mathrm{O}_{5}-\mathrm{SnO}_{2}-\mathrm{IrO} \mathrm{O}_{2}$, and $\mathrm{Pt} / \mathrm{SnO}_{2}$ used for removing X-ray contrast iohexol demonstrated that $\mathrm{Ti} / \mathrm{RuO}_{2}$ provided the highest degradation efficiency [77]. Barış̧̧ et al. [59] found that $\mathrm{Ti}^{\mathrm{RuO}} \mathrm{Ru}_{2}$ could reach complete degradation of carboplatin anti-cancer drug in just $5 \mathrm{~min}$ and obtained zero toxicity at the end of the process. However, the use of $\mathrm{IrO}_{2}, \mathrm{RuO}_{2}$ on large scale is restricted by low abundance, high cost, and difficulty in their separation. $\mathrm{Ir} / \mathrm{IrO}_{2}$ nanoparticles could be immobilized on $\mathrm{Fe}_{3} \mathrm{O}_{4}$ core/ $\mathrm{SiO}_{2}$ shell via surface-modified $\mathrm{NH}_{2}$ functional groups resulted in high catalytic activity, high stability, and efficient recyclability.

\subsubsection{Boron-Doped Diamond}

The BDD anode showed high performance on various kinds of PPCPs, as seen in Table 6. The low-pressure conversion of carbon to diamond crystals has allowed a thin layer of diamond film to develop on suitable substrates like silicon, niobium, tungsten, molybdenum, and titanium [78]. $\mathrm{He}$ et al. [79] examined aspirin degradation with $\mathrm{PbO}_{2}, \mathrm{BDD}$, and porous Ti/BDD as the anode. On BDD electrodes, the electrochemical process involves direct and indirect electrochemical oxidation, whereas, on the $\mathrm{PbO}_{2}$ electrode, only indirect oxidation. The kinetic results can be explained by the mechanism of aspirin degradation, which may take place in two distinct forms: direct oxidation at the electrode surface and indirect oxidation mediated by ${ }^{*} \mathrm{OH}$. In indirect oxidation, the initial step involves the formation of ${ }^{*} \mathrm{OH}$ from water molecule discharge. The oxidation is indirectly mediated by ${ }^{*} \mathrm{OH}$ contributing to the mineralization of organic pollutants. Aspirin mineralization is mainly performed by reaction with ${ }^{*} \mathrm{OH}$. Porous Ti/BDD is the highest excellent potential for aspirin relative to flat BDD and $\mathrm{PbO}_{2}$ electrode when niobium-supported BDD thin film (Nb/BDD) anode could be applied in a wide range of $\mathrm{pH}$, reducing chemicals for $\mathrm{pH}$ adjustment [48].

In various systems, BDD allowed for higher removal rates of PPCPs than other anodes as higher quantities of ${ }^{*} \mathrm{OH}$ produced. Sirés et al. [80] indicated that the performance was demonstrated to be much more productive using a large surface area BDD anode than a Pt one, explained by a large number of active hydroxyl radicals BDD $\left({ }^{*} \mathrm{OH}\right)$ and minimizing their parasitic reactions. Compared to the Pt and glassy carbon anodes, the BDD anode showed better efficiency for isothiazolin-3-one degradation [81]. BDD physisorbed ${ }^{*} \mathrm{OH}$ was observed to cause the combustion of ketoprofen into $\mathrm{CO}_{2}$ and $\mathrm{H}_{2} \mathrm{O}$. The poor mineralization was attributed to the formation of chlorinated organic compounds that are refractory at both BDD and Pt anodes [82]. Omeprazole was primarily oxidized by ${ }^{*} \mathrm{OH}$ formed from water oxidation at the surface of the Pt or BDD [54]. It also can be seen that the BDD anode was superior to the $\mathrm{Pt}$ and $\mathrm{PbO}_{2}$ electrodes for DEET abatement. At the same $\mathrm{j}$ value and temperature, the DEET abatement degradation in the order $\mathrm{BDD}, \mathrm{PbO}_{2}$, and $\mathrm{Pt}[52]$. It also can be seen the higher oxidation power of BDD became evident in removing estrone than $\beta-\mathrm{PbO}_{2}$ anode [83].

BDD electrode in a single compartment filter-press flow cell represented the conversion of cephalexin and its hydroxylated intermediates to $\mathrm{CO}_{2}$ depended solely on their diffusion to the BDD surface. Due to the different types and quantities of electrogenerated oxidants, the oxidation rate of cephalexin using distinct salts as supporting electrolytes showed distinct rates; however, none of them were able to mineralize cephalexin and its intermediates, which only occurred through a diffusion mechanism on the surface of the BDD [84]. Due to the high concentration of ${ }^{*} \mathrm{OH}$ generated on the BDD surface, with the release of $\mathrm{NH}_{4}{ }^{+}$and $\mathrm{NO}_{3}{ }^{-}$ions, nearly $50 \%$ of mineralization of paracetamol and diclofenac is always achieved [50]. 
Table 5. Selected results reported for PPCPs removal by EOP with dimensionally stable anode (DSA) anodes.

\begin{tabular}{|c|c|c|c|c|c|c|c|c|c|c|}
\hline \multirow{2}{*}{ PPCPs } & \multirow{2}{*}{ Initial C } & \multirow{2}{*}{ Electrolyte } & \multirow{2}{*}{$\mathrm{j} / \mathrm{mA} \mathrm{cm}^{-2}$} & \multirow{2}{*}{ Reactors/Operational Parameters } & \multicolumn{2}{|c|}{ Electrodes } & \multirow{2}{*}{$\mathrm{pH}$} & \multirow{2}{*}{$\begin{array}{c}\text { Reaction } \\
\text { Time } \\
\text { (min) }\end{array}$} & \multirow{2}{*}{$\begin{array}{c}\text { Removal } \\
(\%)\end{array}$} & \multirow{2}{*}{$\operatorname{Ref}$} \\
\hline & & & & & Anode & Cathode & & & & \\
\hline Ceftazidime & $5 \mathrm{mg} / \mathrm{L}$ & $\begin{array}{c}1 \mathrm{~g} / \mathrm{L} \\
\mathrm{Na}_{2} \mathrm{SO}_{4}\end{array}$ & 1.25 & $\begin{array}{c}\mathrm{V} \text { reactor and electrolytic } \\
\text { wastewater was } 150 \mathrm{~mL} \text { and } 120 \\
\mathrm{~mL} \text {, respectively }\end{array}$ & $\begin{array}{c}\mathrm{Ti} / \mathrm{TiO}_{2} / \mathrm{SnO}_{2-} \\
\mathrm{Sb}-\mathrm{Cu} \\
(50 \mathrm{~mm} \times 30 \mathrm{~mm} \\
\times 2 \mathrm{~mm})\end{array}$ & $\begin{array}{l}\text { Pt wire; } \\
\text { gap } 4 \mathrm{~cm}\end{array}$ & 6 & - & 97.65 & [75] \\
\hline Iohexol & $0.525 \mathrm{mg} / \mathrm{L}$ & $\begin{array}{c}0.1 \mathrm{M} \\
\mathrm{Na}_{2} \mathrm{SO}_{4}\end{array}$ & $38.1-45$ & $\begin{array}{c}\text { Batch experiments, } \mathrm{V} 350 \mathrm{~mL}, \mathrm{pH} \\
7.2, \text { iohexol concentration } 0.525 \\
\mathrm{mg} / \mathrm{L} ; \mathrm{j}=15,30 \text {, and } 45 \mathrm{~mA} / \mathrm{cm}^{2} \\
\mathrm{pH}(4.0,7.0 \pm 02 \text {, and } 9.0)\end{array}$ & $\begin{array}{l}\mathrm{Ti} / \mathrm{RuO}_{2} \\
25 \mathrm{~cm}^{2}\end{array}$ & $\begin{array}{c}\mathrm{SS} ; \\
0.5-\mathrm{mm} \text { gap }\end{array}$ & 7.1 & $19.8-30$ & $>90$ & {$[77]$} \\
\hline Carboplatin & $0.5 \mathrm{mg} / \mathrm{L}$ & $\begin{array}{c}0.1 \mathrm{M} \\
\mathrm{Na}_{2} \mathrm{SO}_{4}\end{array}$ & 30 & $\begin{array}{c}\text { One-compartment cell } 350 \mathrm{~mL} ; \mathrm{pH} \\
\text { range } 4-9 ; j=15,30 \text { and } 45 \\
\mathrm{~mA} / \mathrm{cm}^{-2}\end{array}$ & $\begin{array}{l}\mathrm{Ti} / \mathrm{RuO}_{2} \\
25 \mathrm{~cm}^{2}\end{array}$ & $\begin{array}{c}\text { SS plate; } \\
25 \mathrm{~cm}^{2} \text { gap } 0.5 \\
\mathrm{~cm}\end{array}$ & 7 & 5 & 100.00 & [59] \\
\hline Methotrexate & $0.5 \mathrm{mg} / \mathrm{L}$ & $\begin{array}{c}200 \mathrm{mg} / \mathrm{L} \\
\mathrm{Na}_{2} \mathrm{SO}_{4}\end{array}$ & 30 & $\begin{array}{c}\text { One-compartment cell, V } 350 \mathrm{~mL} \\
\mathrm{Na}_{2} \mathrm{SO}_{4}(100,200,300 \mathrm{mg} / \mathrm{L}), \mathrm{pH} \\
\text { range of } 4-9 ; \mathrm{j}=15,30 \text { and } 45 \mathrm{~mA} \\
\mathrm{~cm}^{-2}\end{array}$ & $\begin{array}{l}\mathrm{Ti} / \mathrm{IrO}_{2}-\mathrm{RuO}_{2} \\
25 \mathrm{~cm}^{2}\end{array}$ & $\begin{array}{l}\text { SS plate; } 0.5 \\
\text { cm gap }\end{array}$ & 7 & 5 & 95.00 & [85] \\
\hline Estriol & $1000 \mu \mathrm{g} / \mathrm{L}$ & $\begin{array}{c}0.1 \mathrm{M} \\
\mathrm{Na}_{2} \mathrm{SO}_{4}\end{array}$ & 20 & $\begin{array}{l}\text { Batch 3D electrolysis, an undivided } \\
\text { rectangular reactor, V } 300 \mathrm{~mL}, \\
\text { filled with approximately } 50 \mathrm{~g} \\
\text { granular graphite particles and } 70 \\
\text { g glass beads }\end{array}$ & $\begin{array}{l}\mathrm{Ti} / \mathrm{IrO}_{2}-\mathrm{RuO}_{2} \\
5 \times 10 \mathrm{~cm}\end{array}$ & $\begin{array}{l}\mathrm{Ti} ; \\
5 \times 10 \mathrm{~cm} ; \text { gap } \\
\text { could be } \\
\text { adjusted }\end{array}$ & $3-7$ & 50 & 80.00 & [69] \\
\hline Sulfamethoxazole & 200 mg/L & $\begin{array}{l}0.1 \mathrm{~mol} / \mathrm{L} \\
\mathrm{NaCl}\end{array}$ & $\geq 20$ & $\begin{array}{l}\text { Single compartment filter } \\
\text { press-type flow cell reactor, flow } \\
\text { rate: } 425 \mathrm{~mL} / \mathrm{min}\end{array}$ & $\begin{array}{l}\mathrm{Ti} / \mathrm{Ru}_{0.3} \mathrm{Ti}_{0.7} \mathrm{O} \\
14 \mathrm{~cm}^{2}\end{array}$ & $\begin{array}{c}\text { Ti plate; } \\
\text { The same } \\
\text { geometric area }\end{array}$ & 3 & 30 & $>98$ & [86] \\
\hline $\begin{array}{l}\text { Ceftriaxone } \\
\text { sodium }\end{array}$ & $10 \mathrm{mg} / \mathrm{L}$ & $\begin{array}{l}0.1 \mathrm{~mol} / \mathrm{L} \\
\mathrm{Na}_{2} \mathrm{SO}_{4}\end{array}$ & $\begin{array}{l}\text { (The } \\
\text { external } \\
\text { potential } \\
\text { of }+2.0 \mathrm{~V})\end{array}$ & $\begin{array}{l}\text { A cylindrical glass reactor made, } \\
\text { fused and sealed at one end }\end{array}$ & $\mathrm{TiO}_{2}(40) /$ Nano-G & $\begin{array}{l}\text { Titanium } \\
\text { mesh; } \\
\text { gap } 2 \mathrm{~cm}\end{array}$ & - & 120 & 97.70 & [87] \\
\hline Clofibric acid & $50 \mathrm{mg} / \mathrm{L}$ & $\begin{array}{c}50 \mathrm{mM} \\
\mathrm{Na}_{2} \mathrm{SO}_{4}\end{array}$ & 33.6 & $\begin{array}{l}250 \mathrm{~mL} \text { undivided glass beaker } \\
\text { containing } 200 \mathrm{~mL} \text { solution, } \mathrm{T} \\
\text { constant at } 20^{\circ} \mathrm{C} \text {, constant current }\end{array}$ & $\begin{array}{c}\text { Plate mixed metal } \\
\text { oxide }(\mathrm{DSA} \\
\left.\mathrm{Ti}^{2} / \mathrm{RuO}_{2}-\mathrm{IrO}_{2}\right) \\
5.0 \mathrm{~cm} \times 11.9 \mathrm{~cm}\end{array}$ & $\begin{array}{c}\text { SS; } \\
\text { Same } \\
\text { dimension; } \\
\text { gap } 4.0 \mathrm{~cm}\end{array}$ & 4 & 180 & $\begin{array}{l}64.70 \\
(\mathrm{TOC})\end{array}$ & {$[88]$} \\
\hline
\end{tabular}




\subsubsection{Other Electrodes}

The Pt electrode showed better performance in sulfamethoxazole and diclofenac degradation wit electrolyte supports under the same conditions as the carbon electrode [89]. Compared to $\mathrm{RuO}_{2} / \mathrm{Ti}$, $\mathrm{IrO}_{2} / \mathrm{Ti}$, and $\mathrm{RuIrO}_{2} / \mathrm{Ti}$ electrodes, $\mathrm{Pt} / \mathrm{Ti}$ demonstrated that the removal efficiency of berberine was considerably higher [90].

Carbon nanotubes are recognized in wastewater as an advanced anode material for recalcitrant antibiotics for electrocatalysis oxidation. Cyclic voltammetry analysis of $\mathrm{La}_{2} \mathrm{O}_{3}-\mathrm{CuO}_{2} / \mathrm{carbon}$ nanotube (CNT) showed a stronger catalytic activity of the modified electrode and stable working life with an efficiency of $90 \%$ to $1 \mathrm{mg} / \mathrm{L}$ ceftazidime within $30 \mathrm{~min}$, which is much higher than that of pristine CNTs and DSA [91]. The addition of $\mathrm{TiO}_{2}$ could promote the electron transfer and reusability of the $\mathrm{CeO}_{2}-\mathrm{ZrO}_{2} / \mathrm{TiO}_{2} / \mathrm{CNT}$ electrode [92]. In three electrodes promoted by multiwall carbon nanotubes (MWCNTs) (MWCNT, MWCNT-COOH, and MWCNT- $\mathrm{NH}_{2}$ ), concerning the electrode surface chemistry, MWCNT- $\mathrm{NH}_{2}$, with the highest isoelectric point (4.70), is the most promising material due to improved reactant interactions [93].

\subsection{Influence of Operational Parameters}

\subsubsection{Initial PPCPs Concentration}

The initial drug concentration significantly influenced the rate of electrochemical decomposition and the process efficiency for both drugs, ifosfamide, and cyclophosphamide [94]. The higher degradation rate of ibuprofen achieved at relative lower initial concentrations at the initial ibuprofen concentrations ranges from 1.0 to $20.0 \mathrm{mg} / \mathrm{L}$ [66]. The concentration of parabens in the aqueous matrix was the element that, regardless of the aqueous matrix under investigation, exerts a more extraordinary effect on the target variable. An increase in the initial parabens concentration resulted in a decrease in the efficiency of removal [95] and the mineralization rate decreases when salicylic acid concentration rose from $200 \mathrm{mg} / \mathrm{L}$. During bulk electrolyzes at a low $\mathrm{j}$ value and high salicylic acid concentration, salicylic acid was oxidized to aromatic compounds due to a low local concentration on the anode surface of electrogenerated ${ }^{*} \mathrm{OH}$ relative to salicylic acid. As bulk electrolyzes at a high $\mathrm{j}$ value and low salicylic acid concentration, the product was directly combusted to $\mathrm{CO}_{2}$ due to a high local concentration on the anode surface of electrogenerated ${ }^{*} \mathrm{OH}$ relative to salicylic acid [96].

Interestingly, it could be seen that the efficiency improved with the increased concentration of paracetamol and diclofenac due to the gradual increase in the concentration of ${ }^{*} \mathrm{OH}$ to oxidize contaminants before participating in non-oxidizing reactions [50]. The removal of caffeine had two stages, depending on its concentration. At low concentrations, the efficiency significantly increased with $j$ value, suggesting a crucial role of mediated oxidation processes [97].

\subsubsection{Supporting Electrolytes}

In the presence of $\mathrm{NaCl}$ as the supporting electrolyte, the degradation rate of PPCPs was favored. Experiments on $\mathrm{RuO}_{2} / \mathrm{Ti}, \mathrm{IrO}_{2} / \mathrm{Ti}$, $\mathrm{RuIrO}_{2} / \mathrm{Ti}$, and $\mathrm{Pt}$ Ti electrodes showed a constant reaction rate in $\mathrm{NaCl}$ solution three to five times higher than in $\mathrm{Na}_{2} \mathrm{SO}_{4}$ and the oxidation rate of berberines increased due to active chlorine formation [90]. Ambuludi et al. [98] indicated that the pseudo-first-order rate constant increased when $\mathrm{NaCl}$ replaced $\mathrm{Na}_{2} \mathrm{SO}_{4}$ as the electrolyte support and it was almost unaffected by the concentration of ibuprofen. Otherwise, the poor mineralization of ketoprofen was due to the formation of chlorinated organic compounds, which are refractory, at both BDD and Pt anodes in the presence of $\mathrm{NaCl}$ as supporting electrolyte while total mineralization using $\mathrm{Na}_{2} \mathrm{SO}_{4}$ as an electrolyte was achieved [82]. Indermuhle et al. [97] found using $\mathrm{NaCl}$, compared to $\mathrm{Na}_{2} \mathrm{SO}_{4}$, caffeine could reach a faster degradation but more reaction intermediates are formed and the mechanism is consistent with other proposed (Figure 6). 
Table 6. Selected results reported for PPCPs removal by EOP with BDD anodes.

\begin{tabular}{|c|c|c|c|c|c|c|c|c|c|c|}
\hline \multirow{2}{*}{ PPCPs } & \multirow{2}{*}{ Initial C } & \multirow{2}{*}{ Electrolyte } & \multirow{2}{*}{$\begin{array}{l}\mathrm{j} / \mathrm{mA} \\
\mathrm{cm}^{-2}\end{array}$} & \multirow{2}{*}{$\begin{array}{c}\text { Reactors/Operational } \\
\text { Parameters }\end{array}$} & \multicolumn{2}{|c|}{ Electrodes } & \multirow{2}{*}{$\mathrm{pH}$} & \multirow{2}{*}{$\begin{array}{l}\text { Reaction } \\
\text { Time } \\
\text { (min) }\end{array}$} & \multirow{2}{*}{$\begin{array}{c}\text { Removal } \\
(\%)\end{array}$} & \multirow{2}{*}{ Ref. } \\
\hline & & & & & Anode & Cathode & & & & \\
\hline Atenolol & $0.19 \mathrm{mmol} / \mathrm{L}$ & $\begin{array}{c}14 \mathrm{mmol} / \mathrm{L} \\
\mathrm{Na}_{2} \mathrm{SO}_{4}\end{array}$ & 30 & $\begin{array}{c}\text { Double-jacket glass, } \\
\text { one-compartment flow } \\
\text { filter-press reactor, V } 0.002 \\
\mathrm{~m}^{3}, \mathrm{pH}: 3 \text { and } 10 \text {, flow rate } \\
3.33 \times 10^{-5} \mathrm{~m}^{3} \mathrm{~s}^{-1}, \mathrm{j}(5,10,20 \\
\left.\text { and } 30 \mathrm{mAcm}^{-2}\right), \mathrm{T}=25^{\circ} \mathrm{C}\end{array}$ & $\begin{array}{l}\mathrm{Nb} / \mathrm{BDD} 500 \\
0.01 \mathrm{~m}^{2}\end{array}$ & $\begin{array}{l}\text { AISI 304L; } \\
\text { Gap } 0.02 \mathrm{~m}\end{array}$ & 10 & 120 & 100.00 & {$[48]$} \\
\hline Rifampicin & $200 \mathrm{mg} / \mathrm{L}$ & $\begin{array}{l}0.5 \mathrm{~mol} / \mathrm{L} \\
\mathrm{Na}_{2} \mathrm{SO}_{4}\end{array}$ & 90 & $\begin{array}{c}\text { 250-mL undivided open cell, } \\
\text { equipped with magnetic } \\
\text { stirring at } 30^{\circ} \mathrm{C}\end{array}$ & $\begin{array}{c}\text { BDD; } \\
3.0 \times 2.5 \mathrm{~cm}\end{array}$ & $\begin{array}{l}\mathrm{Ti} / \mathrm{Ru}_{0.3} \mathrm{Ti}_{0.7} \mathrm{O}_{2} \\
\quad 4.0 \times 4.0 \mathrm{~cm}\end{array}$ & 3 & 180 & 95.00 & [99] \\
\hline Norfloxacin & $100 \mathrm{mg} / \mathrm{L}$ & $\begin{array}{l}0.1 \mathrm{~mol} / \mathrm{L} \\
\mathrm{Na}_{2} \mathrm{SO}_{4}\end{array}$ & 10 & 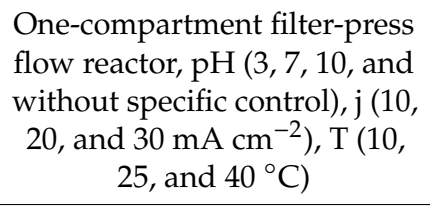 & $\begin{array}{c}\text { BDD; } \\
\text { Thickness of } \\
2.9 \mu \mathrm{m}\end{array}$ & $\begin{array}{l}\text { SS; } \\
\text { area of } 3.54 \mathrm{~cm} \\
\times 6.71 \mathrm{~cm}\end{array}$ & $\begin{array}{l}\text { not pH } \\
\text { depen- } \\
\text { dent }\end{array}$ & 300 & 100.00 & [100] \\
\hline Estrone & $500 \mu \mathrm{g} / \mathrm{L}$ & $\begin{array}{c}0.1 \mathrm{~mol} / \mathrm{L} \\
\mathrm{Na}_{2} \mathrm{SO}_{4}\end{array}$ & 10 & $\begin{array}{l}\text { A filter-press electrochemical } \\
\text { reactor, } 0.5 \mathrm{~L} \text { solution, flow } \\
\text { rate }(2.0,3.0,4.0,5.0,6.0 \text {, and } \\
7.0 \mathrm{~L} / \mathrm{min}), \mathrm{j}(5,10, \text { and } 25 \mathrm{~mA} \\
\left.\mathrm{cm}^{-2}\right), \mathrm{pH}(3.0,7.0, \text { and } 10.0)\end{array}$ & $\begin{array}{c}\text { BDD; } \\
\text { each face was } \\
2.5 \mathrm{~cm} \times 3.0 \\
\mathrm{~cm} 15 \mathrm{~cm}^{2}\end{array}$ & $\begin{array}{c}\mathrm{SS} \\
(3.0 \mathrm{~cm} \times 4.0 \\
\mathrm{cm})\end{array}$ & $<=7$ & 30 & 98.00 & [83] \\
\hline $\begin{array}{c}\text { Paracetamol } \\
\text { Diclofenac }\end{array}$ & $\begin{array}{c}50 \mathrm{mg} / \mathrm{L}, 100 \\
\mathrm{mg} / \mathrm{L}\end{array}$ & $\begin{array}{c}0.05 \mathrm{M} \\
\mathrm{Na}_{2} \mathrm{SO}_{4}\end{array}$ & $1.56-6.25$ & $\begin{array}{c}\text { 4L undivided filter flow press } \\
\text { reactor, } \mathrm{j}(1.56 \text { to } 6.25 \\
\left.\mathrm{mAcm}^{-2}\right) \text {, flow rate kept } \\
\text { constant at } 2 \mathrm{~L} / \mathrm{min}\end{array}$ & $\begin{array}{l}\mathrm{BDD} \\
64 \mathrm{~cm}^{2}\end{array}$ & $\begin{array}{c}\text { SS; } \\
\text { Gap } 2 \mathrm{~cm}\end{array}$ & 3 & 60 & $\begin{array}{l}50.00 \\
(\mathrm{TOC})\end{array}$ & {$[50]$} \\
\hline $\begin{array}{l}\text { Methyl } \\
\text { paraben }\end{array}$ & $100 \mathrm{mg} / \mathrm{L}$ & $\begin{array}{l}0.05 \mathrm{~mol} / \mathrm{L} \\
\mathrm{K}_{2} \mathrm{SO}_{4}\end{array}$ & 10.8 & $\begin{array}{l}\text { One-compartment pyrex cell } \\
(400 \mathrm{~mL}) \text { operated at } 25 \pm 1 \\
{ }^{\circ} \mathrm{C} \text { in batch mode, } \mathrm{j}(1.35 \text { to } \\
\left.21.6 \mathrm{~mA} \mathrm{~cm}^{-2}\right)\end{array}$ & $\begin{array}{c}\mathrm{BDD} ; \\
9.68 \mathrm{~cm}^{-2}\end{array}$ & $\begin{array}{l}\text { Titanium foil; } \\
\text { The same area }\end{array}$ & 5.7 & 300 & 100.00 & [101] \\
\hline Sulfonamides & $50 \mathrm{mg} / \mathrm{L}$ & $\begin{array}{c}6.1 \mathrm{~g} / \mathrm{L} \\
\mathrm{Na}_{2} \mathrm{SO}_{4}\end{array}$ & 15 & $\begin{array}{l}\text { Undivided electrolytic cell, } \mathrm{V} \\
100 \mathrm{~mL}, \mathrm{pH} \text { (from } 2.0 \text { to } 7.4 \text { ), } \\
\mathrm{T} \text { (from } 25 \text { to } 60^{\circ} \mathrm{C} \text { ), and j } \\
\text { (from } 0.05 \text { to } 15 \mathrm{~mA} \mathrm{~cm}^{-2} \text { ) }\end{array}$ & $\begin{array}{l}\mathrm{Si} / \mathrm{BDD} \\
10 \mathrm{~cm}^{2}\end{array}$ & $\begin{array}{c}\text { SS; } \\
\text { Gap } 1 \mathrm{~cm}\end{array}$ & 6.4 & 180 & 92.00 & [102] \\
\hline
\end{tabular}


Table 6. Cont.

\begin{tabular}{|c|c|c|c|c|c|c|c|c|c|c|}
\hline \multirow{2}{*}{ PPCPs } & \multirow{2}{*}{ Initial C } & \multirow{2}{*}{ Electrolyte } & \multirow{2}{*}{$\begin{array}{l}\mathrm{j} / \mathrm{mA} \\
\mathrm{cm}^{-2}\end{array}$} & \multirow{2}{*}{$\begin{array}{c}\text { Reactors/Operational } \\
\text { Parameters }\end{array}$} & \multicolumn{2}{|c|}{ Electrodes } & \multirow{2}{*}{$\mathrm{pH}$} & \multirow{2}{*}{$\begin{array}{l}\text { Reaction } \\
\text { Time } \\
\text { (min) }\end{array}$} & \multirow{2}{*}{$\begin{array}{c}\text { Removal } \\
(\%)\end{array}$} & \multirow{2}{*}{ Ref } \\
\hline & & & & & Anode & Cathode & & & & \\
\hline Tetracycline & $100 \mathrm{mg} / \mathrm{L}$ & $\begin{array}{c}5 \mathrm{~g} / \mathrm{L} \\
\mathrm{Na}_{2} \mathrm{SO}_{4} \text { or } \\
\mathrm{NaCl}\end{array}$ & $\begin{array}{l}25 \text { to } 300 \\
\mathrm{~A} \mathrm{~m}^{-2}\end{array}$ & $\begin{array}{l}\text { Up-flow electrochemical cell, } \\
20 \mathrm{~cm}^{3} \text {, batch mode with } \\
\text { recirculation; } \mathrm{pH}(2 \text { to } 12), \mathrm{j} \\
\left(25 \text { to } 300 \mathrm{~A} \mathrm{~m}^{-2}\right)\end{array}$ & $\begin{array}{l}\mathrm{BDD} ; \\
20 \mathrm{~cm}^{2}\end{array}$ & $\begin{array}{c}\text { SS; } \\
\text { Gap } 1 \mathrm{~cm}\end{array}$ & 5.6 & $30 \mathrm{~min}$ & 100.00 & [103] \\
\hline $\begin{array}{l}\text { Sulfachloropy- } \\
\text { ridazine }\end{array}$ & $0.2 \mathrm{mM}$ & $\begin{array}{c}0.05 \mathrm{M} \\
\mathrm{Na}_{2} \mathrm{SO}_{4}\end{array}$ & $350 \mathrm{~mA}$ & $\begin{array}{l}\text { An open, cylindrical and } \\
\text { undivided glass cell } 250 \mathrm{~mL} \\
\text { with magnetic stirring }\end{array}$ & $\begin{array}{l}\mathrm{BDD} \\
25 \mathrm{~cm}^{2}\end{array}$ & $\begin{array}{l}\text { Carbon-felt; } \\
77 \mathrm{~cm}^{2}(14.0 \\
\mathrm{cm} \times 5.5 \mathrm{~cm})\end{array}$ & 4.5 & $8 \mathrm{~h}$ & 95.00 & [104] \\
\hline Omeprazole & $169 \mathrm{mg} / \mathrm{L}$ & $0.05 \mathrm{Na}_{2} \mathrm{SO}_{4}$ & 100 & $\begin{array}{l}\text { Undivided and cylindrical } \\
\text { glass cell of } 150 \mathrm{~mL} \text {, with a } \\
\text { double jacket, } \mathrm{j}=33.3-150 \\
\mathrm{~mA} \mathrm{~cm}{ }^{-2}, \mathrm{~T}=35^{\circ} \mathrm{C} \text {, stirred } \\
\text { with } 800 \mathrm{rpm}\end{array}$ & $\begin{array}{l}\mathrm{BDD} ; \\
3 \mathrm{~cm}^{2}\end{array}$ & $\begin{array}{l}\text { Carbon-PTFE } \\
\text { air-diffusion; } \\
\text { Gap } 1 \mathrm{~cm}\end{array}$ & 7 & 360 & $\begin{array}{l}78.00 \\
(\mathrm{TOC})\end{array}$ & [54] \\
\hline Ibuprofen & $0.2 \mathrm{mM}$ & $\begin{array}{c}0.05 \mathrm{M} \\
\mathrm{Na}_{2} \mathrm{SO}_{4}\end{array}$ & $\begin{array}{c}50-500 \\
\mathrm{~mA}\end{array}$ & $\begin{array}{c}\text { Cylindrical, open, } \\
\text { one-compartment cell } 200 \\
\mathrm{~mL} \text {, at } \mathrm{T}\left(20 \pm 2{ }^{\circ} \mathrm{C}\right)\end{array}$ & $\begin{array}{l}\mathrm{BDD} ; \\
25 \mathrm{~cm}^{2}\end{array}$ & $\begin{array}{l}\text { Carbon-felt; } \\
14 \mathrm{~cm} \times 5 \mathrm{~cm} \\
\text { each side, } 0.5 \\
\mathrm{~cm} \text { width }\end{array}$ & 3 & 480 & $\begin{array}{c}>96 \\
(\mathrm{TOC})\end{array}$ & [98] \\
\hline
\end{tabular}




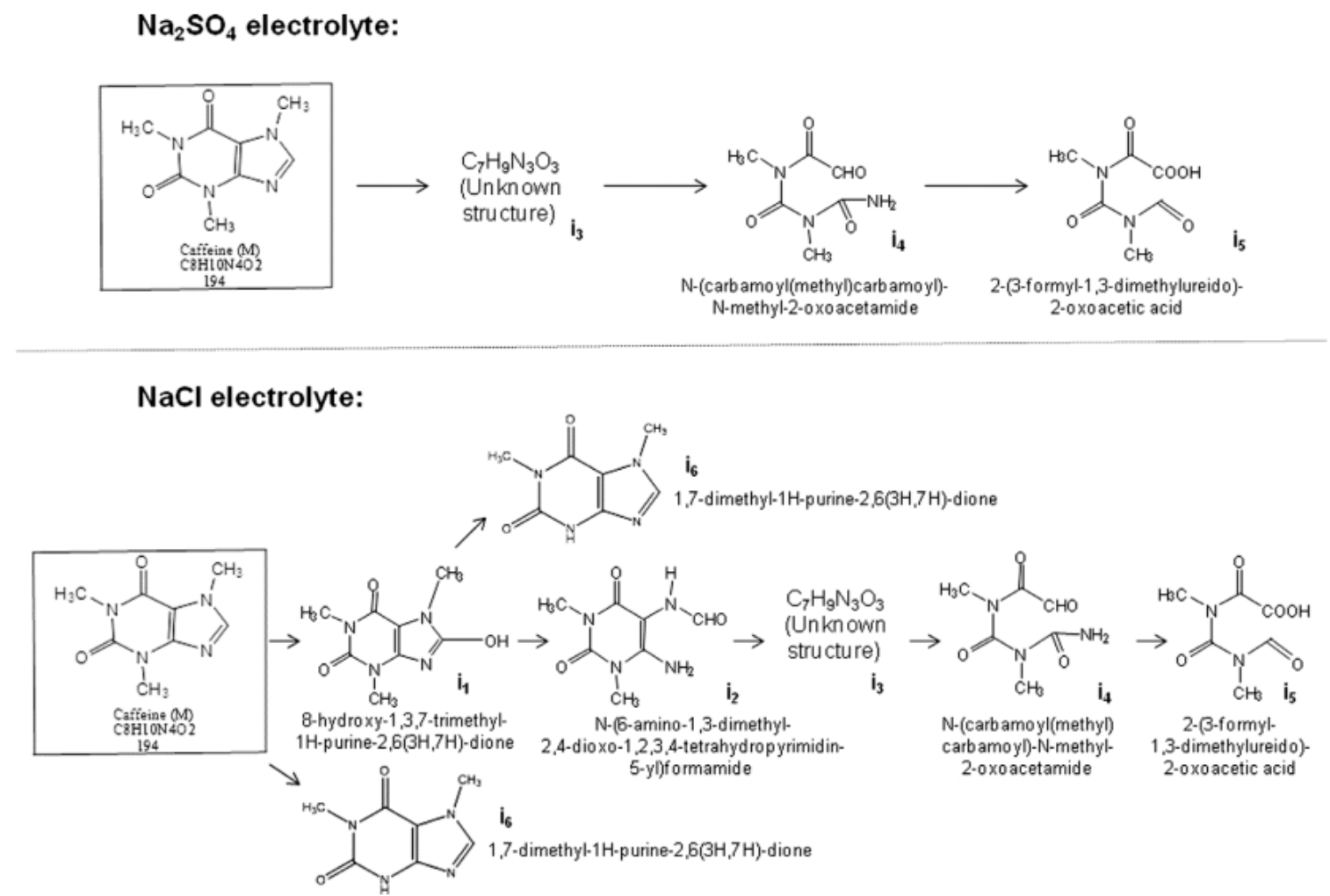

Figure 6. The mechanism model proposed for caffeine degradation by electrochemical oxidation with conductive-diamond electrodes using $\mathrm{Na}_{2} \mathrm{SO}_{4}$ or $\mathrm{NaCl}$ as the electrolyte. Reprinted from Indermuhle et al. [97], copyright (C) (2013) with permission from Elsevier.

In the presence of $\mathrm{Na}_{2} \mathrm{SO}_{4}$, the increasing concentration of $\mathrm{Na}_{2} \mathrm{SO}_{4}$ provided a higher rate of degradation of the anti-cancer drug carboplatin but further increased the concentration of $\mathrm{Na}_{2} \mathrm{SO}_{4}$, which did not offer a higher rate of degradation due to $\mathrm{SO}_{4}{ }^{2-}$ excess [59]. Moreover, $0.1 \mathrm{M}$ electrolyte-supporting $\mathrm{Na}_{2} \mathrm{SO}_{4}$ was found to be more active for sulfamethoxazole and diclofenac mineralization, with an efficiency of $15 \%-30 \%$ higher than $0.1 \mathrm{M}$ electrolyte-supporting phosphate buffer on Pt and carbon electrodes [89].

Various inorganic ions have significant effects on removing certain PPCPs that were compared with a higher removal rate in the presence of chloride species than other ions. Acetaminophen, diclofenac, and sulfamethoxazole degradation showed high removal efficiencies, and faster reaction rates may correlate with the presence of chloride species, which may be due to the involvement of hypochlorite ions. Although all of the drugs were degraded by indirect electrochemical oxidation, cyclic voltammograms suggested that chloride species may have coexisted with ${ }^{*} \mathrm{OH}$ and have been converted into by-products of degradation [49], whereas ions $\mathrm{Cl}^{-}$and $\mathrm{PO}_{4}{ }^{3-}$ significantly increased the decomposition rate of ifosfamide [94].

\subsubsection{Current Density, $\mathrm{pH}$, Temperature, and Stirring Rate}

Current density ( $\mathrm{j}), \mathrm{pH}$, and temperature also among parameters that have been optimized and investigated in the EOP. Which factor most crucial for efficiency removal depends on the kinds of PPCPs, the material of electrodes and the nature of electrolytes applied. For naproxen removal, the current influence was the greatest among these variables, and the second was the salt concentration, the third flow rate and the fourth $\mathrm{pH}$ [105]. Domínguez et al. [106] also proved that the influence of the current was the greatest, then the concentration of salt and the flow rate, respectively, on carbamazepine degradation. 
The $\mathrm{j}$ value shows a vital role in the removal efficiency with increasing removal efficiency when $j$ increased in most cases of PPCPs $[66,97,104]$ and other factors are dependent or not significant under certain operating conditions. Isothiazolin-3-ones degradation rate was faster as the $j$ value applied increased but nearly independent of electrolyte $\mathrm{pH}$ [81]. Moreover, the complete removal of norfloxacin is dependent on $\mathrm{pH}$. However, the removal increased with the temperature at $10{ }^{\circ} \mathrm{C}$, $25^{\circ} \mathrm{C}$, and $40{ }^{\circ} \mathrm{C}$ may result from a gradual increase in the diffusion coefficient and the oxidation of byproducts under temperature conditions [100]. Interestingly, DEET degradation increased with increasing current density but was moderately affected by temperature $\left(25-75^{\circ} \mathrm{C}\right)$ [52]. Similarly, the salicylic acid mineralization rate increased at $25^{\circ} \mathrm{C}$ with an increase of applied current, the $\mathrm{pH}$ impact was not significant [96]. This also can be seen in the case of ketoprofen [82], ifosfamide, and cyclophosphamide [94]. Interestingly, the carboplatin degradation rates increased significantly in the initial phases of electrolysis as $\mathrm{j}$ value increased on the $\mathrm{Ti} / \mathrm{RuO}_{2}$ electrode. However, a further increase in $\mathrm{j}$ did not affect the rate of degradation [59]. Sun et al. [107] found that $\mathrm{pH}$ decreased, the efficiency of chloramphenicol degradation increased, and maximum degradation was achieved at $\mathrm{pH} 2$, Figure 7.

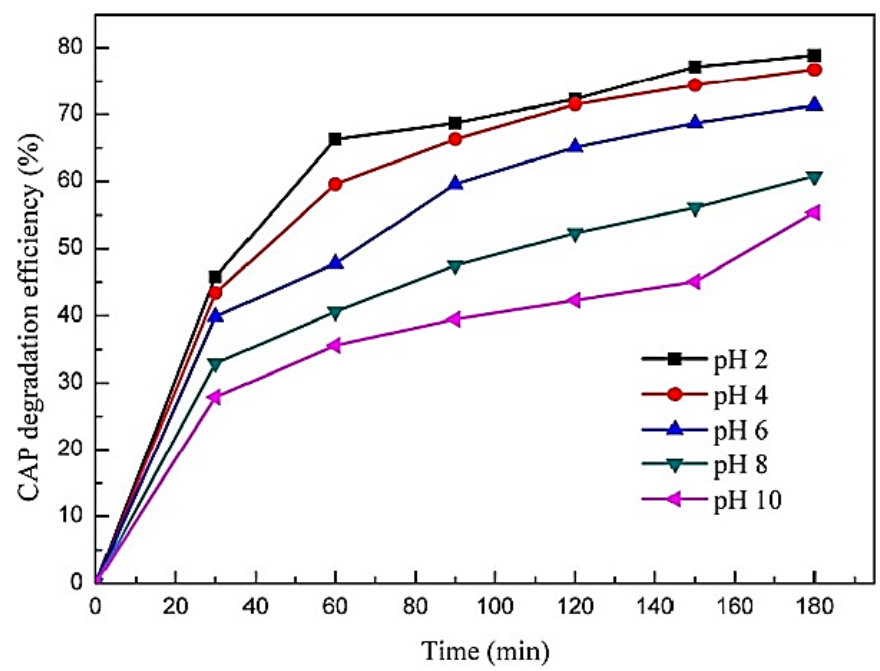

Figure 7. Effect of initial $\mathrm{pH}$ of wastewater on the chloramphenicol degradation efficiency of particle electrodes. Reprinted from Sun et al. [107], copyright (C) (2017) with permission from Elsevier.

Stirring increased the rate of mass transfer and PPCPs formed a contentious relationship on the electrode surface to increase the efficiency of removal. When the stirring speed was too slow, the mass transfer resistance would be the limitation. With the free radical produced from the electrode surface, PPCPs were unable to react quickly. It was also not possible to transfer the hydroxyls produced to the solution in time. On the other hand, the high stirring speed turned leads to short time for PPCPs touching the electrode surface, PPCPs could not be wholly oxidized and soon left the electrode surface. $\mathrm{O}_{2}$ and $\mathrm{H}_{2}$ bubbles produced from $\mathrm{H}_{2} \mathrm{O}$ electrolysis would be more competitive to access molecule surface with extreme disturbance, resulting in reducing removal efficiency. The kinetic study of naproxen degradation at fix potential indicates that the rate of degradation increases with the stirring speed at 250 and $500 \mathrm{rpm}$ [93]. For diffusion reactions, the stirring rate is an essential factor. The stirring rate showed a definite increase in the removal of ceftazidime and then decreased as the stirring speed between 150 and $200 \mathrm{rad} \mathrm{min}^{-1}$ [76].

\subsubsection{Electrode Spacing and Fluid Velocity}

The changes in the spacing of the electrodes would affect not only the mass transfer limitations but also the electron transport and electric resistance [108]. The effect of electrode spacing, however, depends on the direct or indirect oxidation. In the latter case, the electrode spacing should be matched with the diffusion length of ${ }^{*} \mathrm{OH}$ species. Duan, et al. [76] found that the oxidation of ceftazidime 
decreased as the spacing of the $\mathrm{Ti} / \mathrm{SnO}_{2}-\mathrm{Cu}$ electrode changed at 1,2 , and $3 \mathrm{~cm}$ under the current of $20 \mathrm{~mA}$. As the spacing increased, the electrochemical resistance also increased while the charge in the electrolyte decreased. Xie et al. [65] (Figure 8) tested ofloxacin removal with the changes in electrode spacing. The reaction rate increased with the first-order pseudo constant changed as the distance decreased from $3 \mathrm{~cm}$ to $0.5 \mathrm{~cm}$ and the mass transfer coefficient increased.
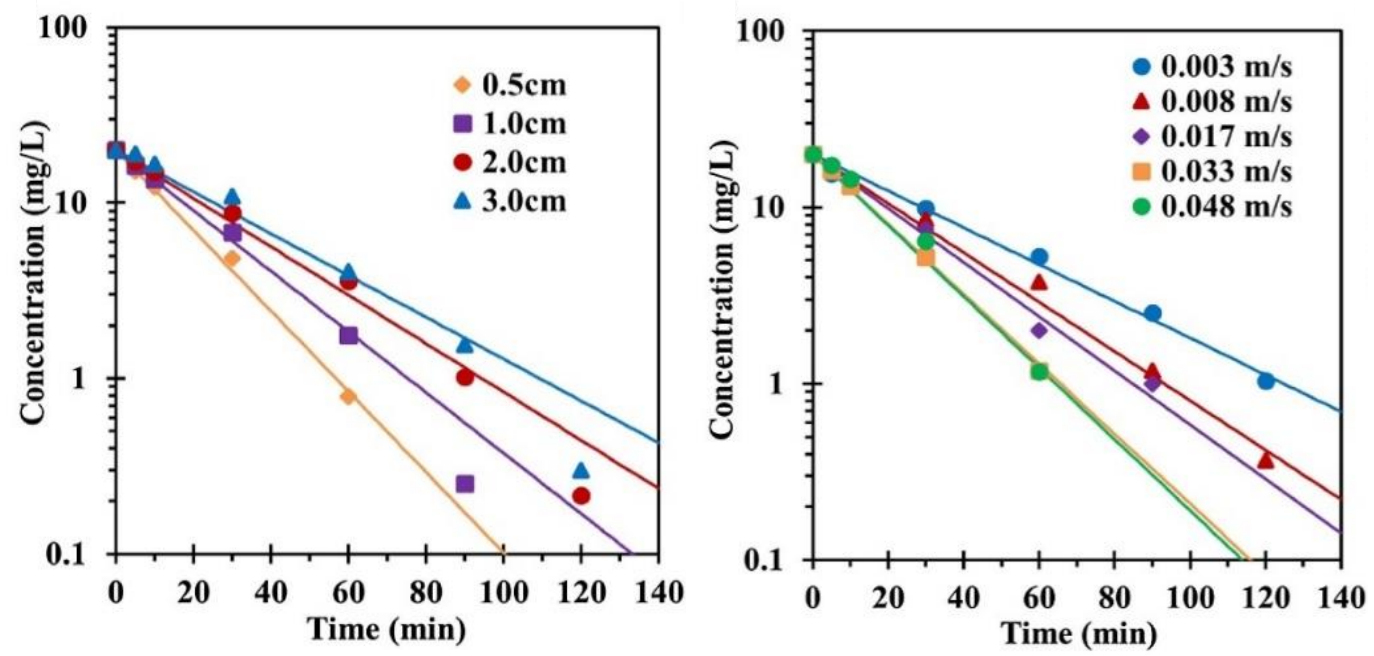

Figure 8. Effect of electrode spacing and fluid velocity on ofloxacin degradation. Anode surface area $10 \mathrm{~cm}^{2}$, electrolyte concentration $=0.05 \mathrm{M} \mathrm{Na}_{2} \mathrm{SO}_{4}$ solution, $\mathrm{j}=30 \mathrm{~mA} \mathrm{~cm}{ }^{-2}$, initial ofloxacin concentration $20 \mathrm{mg} / \mathrm{L}$, voltage 6.2-6.3 V, initial pH 6.25, temperature $25^{\circ} \mathrm{C}$. Reprinted from Xie et al. [65], copyright (C) (2017) with permission from Elsevier.

It can be seen that the electrocatalytic oxidation process relied primarily on the high potential for direct oxidation on the electrode surface and the generation of free radicals for indirect oxidation of PPCPs. Consequently, the spacing increases, which leads to a loss in ${ }^{*} \mathrm{OH}$ production and oxidation power on anode surfaces. Diffusion efficiency also affects removal efficiency and so at a larger electrode spacing, the electrolysis process needs more time because of longer diffusion distance. Both electrode spacing and fluid velocity are critical since increasing velocities that lead to an increase in the rate of mass transfer while decreasing electrode spacing increases the surface area available for mass transfer [65].

\subsection{Applications for Real Water and Wastewater Containing PPCPS}

EOP is a promising technique with different degradation rates for the removal of PPCPs from water and WWTP effluents under optimal conditions concerning the ecological system [98,107,109,110].

Because of the presence of chloride ions in the effluent, oxidation in secondary treated wastewater was faster than in pure water [111]. Carbamazepine electrodegradation is feasible for WWT in several aqueous matrices [112], after 50 min of electrolysis time, caffeine was removed entirely in DIW and was almost removed in the wastewater sample may be related to the organic matter in wastewater. Having regard to these results, EOP is an effective method for further removal of caffeine from effluent from aerobic or anaerobic reactors that treat municipal wastewater, even though a high concentration of caffeine was used compared to low concentration in natural water. Compared to conventional methods for removing caffeine from urban wastewater, this approach appears to be more feasible for the following reasons: ease of operating, rapid removal of caffeine, and the effective efficiency of treatment [110]. The caffeine elimination obtained in real wastewater was found to be higher than in synthetic wastewater due to the contribution of electrogenerated oxidant species, such as hypochlorite [113], when sulfonamides and DEET removal were most efficient in the presence of municipal wastewater treatment plant (MWWTP) effluents [52,102]. 


\subsection{Combined Systems}

While EOP has been widely demonstrated for their ability to remove trace and persistent PPCPs in water and wastewater, complex water matrices could be found that inhibit their efficient operation. As a result, they may potentially reduce or fully retard the efficiency, requiring longer hydraulic retention time or higher volume capacity for compensation. System hybridization or combination of EOP with other water technologies is possible to overcome the operational problems associated with the complex water matrices.

Zaghdoudi et al. [114] investigated the possibility of coupling an electroreduction pretreatment before a biological process for dimetridazole removal. Direct electrolysis was initially conducted at the low potential to reduce amino derivatives formation and then azo dimer formation with a total degradation of dimetridazole achieved and the ratio of biochemical oxygen demand $\left(\mathrm{BOD}_{5}\right) / \mathrm{chemical}$ oxygen demand (COD) increased. As mineralization yields of all electrolyzed solutions increased significantly, the enhancement of biodegradability was demonstrated during biological treatment. Nevertheless, the real mineralization yields should most likely be significantly higher if the contribution of titanocene, which is possibly biorecalcitrant, is not taken into account in the amount of TOC. Belkheiri et al. [115] examined the biodegradability improvement of tetracycline-containing solutions after an electrochemical pretreatment, as a large amount of the applied drugs are not metabolized and, therefore, can be found in wastewater. $\mathrm{BOD}_{5}$ measurements verified biodegradability increased with the oxidation potential as the ratio of $\mathrm{BOD}_{5} / \mathrm{COD}$ increased. Despite its chemical transformation, none of the reduced tetracycline solutions are biodegradable. Yahiaoui et al. [116] found after $5 \mathrm{~h}$ of electrochemical pre-treatment of tetracycline, the $\mathrm{BOD}_{5} / \mathrm{COD}$ ratio increased considerably and confirmed during biological treatment, with $76 \%$ of dissolved organic carbon (DOC) removed.

Pharmaceutical degradation in conventional WWTPs is a problem because industrial sewage and hospital effluents contain low-concentration pharmaceuticals. Rodríguez-Nava et al. [117] found high efficiencies in removal without affecting activated sludge performance of integrating EOP with a biological system for simultaneous removal from wastewater of recalcitrant drugs (bezafibrate, gemfibrozil, indomethacin, and sulfamethoxazole). Drugs contained in wastewater without electrochemical pretreatment was persistent in the biological process and encouraged bulking formation. García-Gómez et al. [118] proved membrane bioreactor (MBR) high capacity to remove COD and low capacity for degradation (20\%) of carbamazepine after 120 days, which presumably suggests that given the weak degradation and carbamazepine was not toxic to microorganisms. The EOP, on the other hand, was able to degrade carbamazepine completely.

In an exciting study for investigating pre- and post-treatment in one system to remove synthetic hospital wastewater fortified with four drug pollutants including carbamazepine, ibuprofen, estradiol, and venlafaxine by the combination of MBR and EOP, MBR alone treatment of wastewater showed a high percentage of ibuprofen and estradiol removal (about 90\%), while carbamazepine and venlafaxine performed a low elimination (at around 10\%). EOP as post-treatment, this allowed high removal (about $97 \%$ ) of the four pharmaceutical pollutants and far more successful compared to EOP as pre-treatment [119]. The integration of electrochemical processes into MBR systems can utilize the mechanism of biodegradation, sorption, hydrolysis, and filtration on conventional MBR and electrocoagulation, electroosmosis, and electrophoresis on electrochemical processes that improve both the performance and the control of membrane fouling for eliminating recalcitrant micropollutants [120,121].

\section{Conclusions}

EOP is a promising technique with different degradation rates for the removal of PPCPs from water and wastewater, from synthetic or real, concerning the ecological system. There are numerous studies that have recently focused on the finding of electrode materials and optimal conditions, including initial PPCPs concentration, supporting electrolytes, $\mathrm{j}$ value, $\mathrm{pH}$, temperature, stirring rate, and electrode spacing that are effective for removing a certain or groups of PPCPs with considering reduce operating 
cost. In terms of operational parameters, it was shown that the current influence was the greatest among these variables in some mentioned studies. Although the electrochemical process has recorded several influential factors, only some of them show a significant impact on real systems.

Studies showed that the EOP system depends heavily on the type of anode. BDD anode shows high performance on various kinds of PPCPs. The BDD anodes have been reported to produce higher organic oxidation rates and higher current efficiencies than other metal oxides commonly used. The development of BDD anodes and the enormous advantages of this electrode compared to others make this material was investigated on most of the works published in the literature. The performance of 3D electrolysis is much better, more cost-effective, and saves more energy consumption than traditional 2D electrolysis. The results validate 3D electrolysis in pretreatment or advanced treatment applications as a promising alternative method to remove PPCPs from secondary effluents.

Real field samples may contain other species of radical electrolytes that may participate in the electrochemical process and therefore act as interferences within the EOP system. It is therefore recommended that the electrochemical degradation process be the last step in the domestic water treatment since the technique also largely depends on the electrolytes in the water.

Toxicity evaluation is an essential environmental pollution control factor since the degradation by-products from the initial structure can be more toxic. It can be seen that in some kinds of PPCPs, intermediates are more toxic than the molecule of the parent, while others are less harmful. By evaluating toxicity, it helps significantly in optimizing treatment conditions to achieve the elimination of adverse effects of by-products.

EOP has widely demonstrated their ability to remove trace and persistent PPCPs in water and wastewater. Further, complex water matrices could be found that inhibit their efficient operation. System hybridization or combination of EOP with other water technologies is possible to overcome the operational problems associated with the complex water matrices.

Author Contributions: Conceptualization, K.C.D., Y.-P.T. and K.-F.C.; resources, Y.-P.T. and K.-F.C; writing-original draft preparation, K.C.D.; writing-review and editing, K.C.D., and C.-C.Y.; supervision, Y.-P.T. and K.-F.C.; project administration, C.-C.Y.; funding acquisition, Y.-P.T. All authors have read and agreed to the published version of the manuscript.

Funding: This research was funded by the Ministry of Science and Technology, Taiwan, grant number MOST 106-2221-E-260-003-MY3.

Conflicts of Interest: The authors declare no conflicts of interest.

\section{References}

1. Shen, R.; Andrews, S.A. Demonstration of 20 pharmaceuticals and personal care products (PPCPs) as nitrosamine precursors during chloramine disinfection. Water Res. 2011, 45, 944-952. [CrossRef] [PubMed]

2. Boxall, A.B.; Rudd, M.A.; Brooks, B.W.; Caldwell, D.J.; Choi, K.; Hickmann, S.; Innes, E.; Ostapyk, K.; Staveley, J.P.; Verslycke, T. Pharmaceuticals and personal care products in the environment: What are the big questions? Environ. Health Perspect. 2012, 120, 1221-1229. [CrossRef]

3. Deblonde, T.; Cossu-Leguille, C.; Hartemann, P. Emerging pollutants in wastewater: A review of the literature. Int. J. Hyg. Environ. Health 2011, 214, 442-448. [CrossRef]

4. Rajapaksha, A.U.; Vithanage, M.; Lim, J.E.; Ahmed, M.B.M.; Zhang, M.; Lee, S.S.; Ok, Y.S. Invasive plant-derived biochar inhibits sulfamethazine uptake by lettuce in soil. Chemosphere 2014, 111, 500-504. [CrossRef] [PubMed]

5. Helbling, D.E.; Hollender, J.; Kohler, H.-P.E.; Singer, H.; Fenner, K. High-throughput identification of microbial transformation products of organic micropollutants. Environ. Sci. Technol. Water Treat. 2010, 44, 6621-6627. [CrossRef] [PubMed]

6. Xia, K.; Bhandari, A.; Das, K.; Pillar, G. Occurrence and fate of pharmaceuticals and personal care products (PPCPs) in biosolids. J. Environ. Qual. 2005, 34, 91-104. [CrossRef]

7. Blair, B.D.; Crago, J.P.; Hedman, C.J.; Klaper, R.D. Pharmaceuticals and personal care products found in the Great Lakes above concentrations of environmental concern. Chemosphere 2013, 93, 2116-2123. [CrossRef] 
8. Chiron, S.; Minero, C.; Vione, D. Photodegradation processes of the antiepileptic drug carbamazepine, relevant to estuarine waters. Environ. Sci. 2006, 40, 5977-5983. [CrossRef]

9. Tolls, J. Sorption of veterinary pharmaceuticals in soils: A review. Environ. Sci. Technol. Water Treat. 2001, 35, 3397-3406. [CrossRef]

10. Panizza, M.; Cerisola, G. Direct and mediated anodic oxidation of organic pollutants. Chem. Rev. 2009, 109, 6541-6569. [CrossRef]

11. Hollender, J.; Zimmermann, S.G.; Koepke, S.; Krauss, M.; McArdell, C.S.; Ort, C.; Singer, H.; von Gunten, U.; Siegrist, H. Elimination of organic micropollutants in a municipal wastewater treatment plant upgraded with a full-scale post-ozonation followed by sand filtration. Environ. Sci. Technol. Water Treat. 2009, 43, 7862-7869. [CrossRef]

12. Martinez-Huitle, C.A.; Ferro, S. Electrochemical oxidation of organic pollutants for the wastewater treatment: Direct and indirect processes. Chem. Soc. Rev. 2006, 35, 1324-1340. [CrossRef]

13. Kaestner, M.; Nowak, K.M.; Miltner, A.; Trapp, S.; Schaeffer, A. Classification and modelling of nonextractable residue (NER) formation of xenobiotics in soil-a synthesis. Crit. Rev. Environ. Sci. Technol. Water Treat. 2014, 44, 2107-2171. [CrossRef]

14. Kallenborn, R. Perfluorinated Alkylated Substances (PFAS) in the Nordic Environment; Nordic Council of Ministers: Copenhagen, Denmark, 2004.

15. Daughton, C.G.; Ternes, T.A. Pharmaceuticals and personal care products in the environment: Agents of subtle change? Environ. Health Perspect. 1999, 107, 907-938. [CrossRef] [PubMed]

16. Golet, E.M.; Alder, A.C.; Hartmann, A.; Ternes, T.A.; Giger, W. Trace determination of fluoroquinolone antibacterial agents in urban wastewater by solid-phase extraction and liquid chromatography with fluorescence detection. Anal. Chem. 2001, 73, 3632-3638. [CrossRef]

17. Lishman, L.; Smyth, S.A.; Sarafin, K.; Kleywegt, S.; Toito, J.; Peart, T.; Lee, B.; Servos, M.; Beland, M.; Seto, P. Occurrence and reductions of pharmaceuticals and personal care products and estrogens by municipal wastewater treatment plants in Ontario, Canada. Sci. Total Environ. 2006, 367, 544-558. [CrossRef]

18. Roberts, J.; Kumar, A.; Du, J.; Hepplewhite, C.; Ellis, D.J.; Christy, A.G.; Beavis, S.G. Pharmaceuticals and personal care products (PPCPs) in Australia's largest inland sewage treatment plant, and its contribution to a major Australian river during high and low flow. Sci. Total Environ. 2016, 541, 1625-1637. [CrossRef] [PubMed]

19. Yu, Y.; Wu, L.; Chang, A.C. Seasonal variation of endocrine disrupting compounds, pharmaceuticals and personal care products in wastewater treatment plants. Sci. Total Environ. 2013, 442, 310-316. [CrossRef] [PubMed]

20. Martín, J.; Camacho-Muñoz, D.; Santos, J.L.; Aparicio, I.; Alonso, E. Occurrence and ecotoxicological risk assessment of 14 cytostatic drugs in wastewater. Water Air Soil Pollut. 2014, 225, 1896. [CrossRef]

21. Ternes, T.A.; Bonerz, M.; Herrmann, N.; Teiser, B.; Andersen, H.R. Irrigation of treated wastewater in Braunschweig, Germany: An option to remove pharmaceuticals and musk fragrances. Chemosphere 2007, 66, 894-904. [CrossRef]

22. Qiu, G.; Song, Y.-H.; Zeng, P.; Duan, L.; Xiao, S. Characterization of bacterial communities in hybrid upflow anaerobic sludge blanket (UASB)-membrane bioreactor (MBR) process for berberine antibiotic wastewater treatment. Bioresour. Technol. 2013, 142, 52-62. [CrossRef]

23. Rosal, R.; Rodríguez, A.; Perdigón-Melón, J.A.; Petre, A.; García-Calvo, E.; Gómez, M.J.; Agüera, A.; Fernández-Alba, A.R. Occurrence of emerging pollutants in urban wastewater and their removal through biological treatment followed by ozonation. Water Res. 2010, 44, 578-588. [CrossRef]

24. Leclercq, M.; Mathieu, O.; Gomez, E.; Casellas, C.; Fenet, H.; Hillaire-Buys, D. Presence and fate of carbamazepine, oxcarbazepine, and seven of their metabolites at wastewater treatment plants. Arch. Environ. Contam. Toxicol. 2009, 56, 408. [CrossRef] [PubMed]

25. Lenz, K.; Hann, S.; Koellensperger, G.; Stefanka, Z.; Stingeder, G.; Weissenbacher, N.; Mahnik, S.N.; Fuerhacker, M. Presence of cancerostatic platinum compounds in hospital wastewater and possible elimination by adsorption to activated sludge. Sci. Total Environ. 2005, 345, 141-152. [CrossRef]

26. Liu, Y.; Wang, Z.; Yan, K.; Wang, Z.; Torres, O.L.; Guo, R.; Chen, J. A new disposal method for systematically processing of ceftazidime: The intimate coupling UV/algae-algae treatment. Chem. Eng. J. 2017, 314, 152-159. [CrossRef] 
27. Junker, T.; Alexy, R.; Knacker, T.; Kümmerer, K. Biodegradability of 14C-labeled antibiotics in a modified laboratory scale sewage treatment plant at environmentally relevant concentrations. Environ. Sci. Technol. 2006, 40, 318-324. [CrossRef] [PubMed]

28. Watkinson, A.J.; Murby, E.J.; Costanzo, S.D. Removal of antibiotics in conventional and advanced wastewater treatment: Implications for environmental discharge and wastewater recycling. Water Res. 2007, 41, 4164-4176. [CrossRef]

29. Leung, H.W.; Minh, T.B.; Murphy, M.B.; Lam, J.C.; So, M.K.; Martin, M.; Lam, P.K.; Richardson, B.J. Distribution, fate and risk assessment of antibiotics in sewage treatment plants in Hong Kong, South China. Environ. Int. 2012, 42, 1-9. [CrossRef]

30. Xu, W.; Zhang, G.; Li, X.; Zou, S.; Li, P.; Hu, Z.; Li, J. Occurrence and elimination of antibiotics at four sewage treatment plants in the Pearl River Delta (PRD), South China. Water Res. 2007, 41, 4526-4534. [CrossRef]

31. Blair, B.; Nikolaus, A.; Hedman, C.; Klaper, R.; Grundl, T. Evaluating the degradation, sorption, and negative mass balances of pharmaceuticals and personal care products during wastewater treatment. Chemosphere 2015, 134, 395-401. [CrossRef]

32. Salgado, R.; Oehmen, A.; Carvalho, G.; Noronha, J.P.; Reis, M.A. Biodegradation of clofibric acid and identification of its metabolites. J. Hazard. Mater. 2012, 241, 182-189. [CrossRef]

33. Sun, Q.; Lv, M.; Hu, A.; Yang, X.; Yu, C.P. Seasonal variation in the occurrence and removal of pharmaceuticals and personal care products in a wastewater treatment plant in Xiamen, China. J. Hazard. Mater. 2014, 277, 69-75. [CrossRef] [PubMed]

34. He, K.; Soares, A.D.; Adejumo, H.; McDiarmid, M.; Squibb, K.; Blaney, L. Detection of a wide variety of human and veterinary fluoroquinolone antibiotics in municipal wastewater and wastewater-impacted surface water. J. Pharm. Biomed. Anal. 2015, 106, 136-143. [CrossRef]

35. Voets, J.P.; Pipyn, P.; Van Lancker, P.; Verstraete, W. Degradation of microbicides under different environmental conditions. J. Appl. Bacteriol. 1976, 40, 67-72. [CrossRef]

36. Prasse, C.; Schlusener, M.P.; Schulz, R.; Ternes, T.A. Antiviral drugs in wastewater and surface waters: A new pharmaceutical class of environmental relevance? Environ. Sci. Technol. 2010, 44, 1728-1735. [CrossRef] [PubMed]

37. Simonich, S.L.; Federle, T.W.; Eckhoff, W.S.; Rottiers, A.; Webb, S.; Sabaliunas, D.; De Wolf, W. Removal of fragrance materials during US and European wastewater treatment. Environ. Sci. Technol. 2002, 36, 2839-2847. [CrossRef] [PubMed]

38. Nakada, N.; Tanishima, T.; Shinohara, H.; Kiri, K.; Takada, H. Pharmaceutical chemicals and endocrine disrupters in municipal wastewater in Tokyo and their removal during activated sludge treatment. Water Res. 2006, 40, 3297-3303. [CrossRef]

39. Molins-Delgado, D.; Díaz-Cruz, M.S.; Barceló, D. Ecological risk assessment associated to the removal of endocrine-disrupting parabens and benzophenone-4 in wastewater treatment. J. Hazard. Mater. 2016, 310, 143-151. [CrossRef]

40. Zhang, X.; Zhao, H.; Du, J.; Qu, Y.; Shen, C.; Tan, F.; Chen, J.; Quan, X. Occurrence, removal, and risk assessment of antibiotics in 12 wastewater treatment plants from Dalian, China. Environ. Sci. Pollut. Res. Int. 2017, 24, 16478-16487. [CrossRef]

41. Kosma, C.I.; Lambropoulou, D.A.; Albanis, T.A. Occurrence and removal of PPCPs in municipal and hospital wastewaters in Greece. J. Hazard. Mater. 2010, 179, 804-817. [CrossRef]

42. Verlicchi, P.; Al Aukidy, M.; Zambello, E. Occurrence of pharmaceutical compounds in urban wastewater: Removal, mass load and environmental risk after a secondary treatment-A review. Sci. Total Environ. 2012, 429, 123-155. [CrossRef]

43. Huddleston, J.G.; Willauer, H.D.; Swatloski, R.P.; Visser, A.E.; Rogers, R.D. Room temperature ionic liquids as novel media for 'clean'liquid-liquid extraction. Chem. Commun. 1998, 1765-1766. [CrossRef]

44. Mohammadhosseini, M.; Tehrani, M.S.; Ganjali, M.R. Preconcentration, determination and speciation of chromium (III) using solid phase extraction and flame atomic absorption spectrometry. J. Chin. Chem. Soc. 2006, 53, 549-557. [CrossRef]

45. Rajeshwar, K.; Ibanez, J.G. Environmental Electrochemistry: Fundamentals and Applications in Pollution Sensors and Abatement; Elsevier: Amsterdam, The Netherlands, 1997.

46. Wendt, H.; Kreysa, G. Electrochemical Engineering: Science and Technology in Chemical and Other Industries; Springer: Berlin/Heidelberg, Germany, 1999. 
47. Periyasamy, S.; Muthuchamy, M. Electrochemical oxidation of paracetamol in water by graphite anode: Effect of $\mathrm{pH}$, electrolyte concentration and current density. J. Environ. Chem. Eng. 2018, 6, 7358-7367. [CrossRef]

48. Da Silva, S.W.; do Prado, J.M.; Heberle, A.N.A.; Schneider, D.E.; Rodrigues, M.A.S.; Bernardes, A.M. Electrochemical advanced oxidation of Atenolol at $\mathrm{Nb} / \mathrm{BDD}$ thin film anode. J. Electroanal. Chem. 2019, 844, 27-33. [CrossRef]

49. Liu, Y.-J.; Hu, C.-Y.; Lo, S.-L. Direct and indirect electrochemical oxidation of amine-containing pharmaceuticals using graphite electrodes. J. Hazard. Mater. 2019, 366, 592-605. [CrossRef]

50. García-Montoya, M.F.; Gutiérrez-Granados, S.; Alatorre-Ordaz, A.; Galindo, R.; Ornelas, R.; Peralta-Hernandez, J.M.; Chemistry, E. Application of electrochemical/BDD process for the treatment wastewater effluents containing pharmaceutical compounds. J. Ind. Eng. Chem. 2015, 31, 238-243. [CrossRef]

51. Mora-Gomez, J.; Ortega, E.; Mestre, S.; Pérez-Herranz, V.; García-Gabaldón, M. Electrochemical degradation of norfloxacin using BDD and new Sb-doped $\mathrm{SnO}_{2}$ ceramic anodes in an electrochemical reactor in the presence and absence of a cation-exchange membrane. Sep. Purif. Technol. 2019, 208, 68-75. [CrossRef]

52. Chen, T.-S.; Chen, P.-H.; Huang, K.-L. Electrochemical degradation of N, N-diethyl-m-toluamide on a boron-doped diamond electrode. J. Taiwan Inst. Chem. Eng. 2014, 45, 2615-2621. [CrossRef]

53. Brillas, E.; Sires, I.; Arias, C.; Cabot, P.L.; Centellas, F.; Rodriguez, R.M.; Garrido, J.A. Mineralization of paracetamol in aqueous medium by anodic oxidation with a boron-doped diamond electrode. Chemosphere 2005, 58, 399-406. [CrossRef]

54. Cavalcanti, E.B.; Garcia-Segura, S.; Centellas, F.; Brillas, E. Electrochemical incineration of omeprazole in neutral aqueous medium using a platinum or boron-doped diamond anode: Degradation kinetics and oxidation products. Water Res. 2013, 47, 1803-1815. [CrossRef]

55. Dai, Q.; Xia, Y.; Sun, C.; Weng, M.; Chen, J.; Wang, J.; Chen, J. Electrochemical degradation of levodopa with modified $\mathrm{PbO}_{2}$ electrode: Parameter optimization and degradation mechanism. Chem. Eng. J. 2014, 245, 359-366. [CrossRef]

56. Radjenovic, J.; Bagastyo, A.; Rozendal, R.A.; Mu, Y.; Keller, J.; Rabaey, K. Electrochemical oxidation of trace organic contaminants in reverse osmosis concentrate using $\mathrm{RuO}_{2} / \mathrm{IrO}_{2}$-coated titanium anodes. Water Res. 2011, 45, 1579-1586. [CrossRef]

57. Sopaj, F.; Rodrigo, M.A.; Oturan, N.; Podvorica, F.I.; Pinson, J.; Oturan, M.A. Influence of the anode materials on the electrochemical oxidation efficiency. Application to oxidative degradation of the pharmaceutical amoxicillin. Chem. Eng. J. 2015, 262, 286-294. [CrossRef]

58. Oaks, J.L.; Gilbert, M.; Virani, M.Z.; Watson, R.T.; Meteyer, C.U.; Rideout, B.A.; Shivaprasad, H.; Ahmed, S.; Chaudhry, M.J.I.; Arshad, M. Diclofenac residues as the cause of vulture population decline in Pakistan. Nature 2004, 427, 630. [CrossRef]

59. Barışçı, S.; Turkay, O.; Ulusoy, E.; Soydemir, G.; Seker, M.G.; Dimoglo, A. Electrochemical treatment of anti-cancer drug carboplatin on mixed-metal oxides and boron doped diamond electrodes: Density functional theory modelling and toxicity evaluation. J. Hazard. Mater. 2018, 344, 316-321. [CrossRef]

60. El-Ashtoukhy, E.-S.; Amin, N.; Abdelwahab, O. Treatment of paper mill effluents in a batch-stirred electrochemical tank reactor. Chem. Eng. J. 2009, 146, 205-210. [CrossRef]

61. Wang, Q.; Jin, T.; Hu, Z.; Zhou, L.; Zhou, M. TiO $2-\mathrm{NTs} / \mathrm{SnO}_{2}-\mathrm{Sb}$ anode for efficient electrocatalytic degradation of organic pollutants: Effect of $\mathrm{TiO}_{2}-\mathrm{NTs}$ architecture. Sep. Purif. Technol. 2013, 102, 180-186. [CrossRef]

62. Wu, W.; Huang, Z.-H.; Lim, T.-T. Recent development of mixed metal oxide anodes for electrochemical oxidation of organic pollutants in water. Appl. Catal. A Gen. 2014, 480, 58-78. [CrossRef]

63. Dai, Q.; Zhou, J.; Meng, X.; Feng, D.; Wu, C.; Chen, J. Electrochemical oxidation of cinnamic acid with Mo modified $\mathrm{PbO}_{2}$ electrode: Electrode characterization, kinetics and degradation pathway. Chem. Eng. J. 2016, 289, 239-246. [CrossRef]

64. Zhao, W.; Xing, J.; Chen, D.; Jin, D.; Shen, J. Electrochemical degradation of Musk ketone in aqueous solutions using a novel porous $\mathrm{Ti} / \mathrm{SnO}_{2}-\mathrm{Sb}_{2} \mathrm{O}_{3} / \mathrm{PbO}_{2}$ electrodes. J. Electroanal. Chem. 2016, 775, 179-188. [CrossRef]

65. Xie, R.; Meng, X.; Sun, P.; Niu, J.; Jiang, W.; Bottomley, L.; Li, D.; Chen, Y.; Crittenden, J. Electrochemical oxidation of ofloxacin using a $\mathrm{TiO}_{2}$-based $\mathrm{SnO}_{2}-\mathrm{Sb}$ /polytetrafluoroethylene resin- $\mathrm{PbO}_{2}$ electrode: Reaction kinetics and mass transfer impact. Appl. Catal. B Environ. 2017, 203, 515-525. [CrossRef]

66. Wang, C.; Yu, Y.; Yin, L.; Niu, J.; Hou, L.-A. Insights of ibuprofen electro-oxidation on metal-oxide-coated Ti anodes: Kinetics, energy consumption and reaction mechanisms. Chemosphere 2016, 163, 584-591. [CrossRef] [PubMed] 
67. Brillas, E.; Martínez-Huitle, C.A. Decontamination of wastewaters containing synthetic organic dyes by electrochemical methods. An updated review. Appl. Catal. B Environ. 2015, 166, 603-643. [CrossRef]

68. Alighardashi, A.; Aghta, R.S.; Ebrahimzadeh, H. Improvement of Carbamazepine Degradation by a Three-Dimensional Electrochemical (3-EC) Process. Int. J. Environ. Res. Public Health 2018, 12, 451-458. [CrossRef]

69. Shen, B.; Wen, X.-H.; Huang, X. Enhanced removal performance of estriol by a three-dimensional electrode reactor. Chem. Eng. J. 2017, 327, 597-607. [CrossRef]

70. Wang, Y.; Zhou, C.; Chen, J.; Fu, Z.; Niu, J. Bicarbonate enhancing electrochemical degradation of antiviral drug lamivudine in aqueous solution. J. Electroanal. Chem. 2019, 848, 113314. [CrossRef]

71. Wachter, N.; Aquino, J.M.; Denadai, M.; Barreiro, J.C.; Silva, A.J.; Cass, Q.B.; Rocha-Filho, R.C.; Bocchi, N. Optimization of the electrochemical degradation process of the antibiotic ciprofloxacin using a double-sided $\beta-\mathrm{PbO}_{2}$ anode in a flow reactor: Kinetics, identification of oxidation intermediates and toxicity evaluation. Environ. Sci. Pollut. Res. 2019, 26, 4438-4449. [CrossRef]

72. Wang, C.; Yin, L.; Xu, Z.; Niu, J.; Hou, L.-A. Electrochemical degradation of enrofloxacin by lead dioxide anode: Kinetics, mechanism and toxicity evaluation. Chem. Eng. J. 2017, 326, 911-920. [CrossRef]

73. Wei, L.; Guo, S.; Yan, G.; Chen, C.; Jiang, X. Electrochemical pretreatment of heavy oil refinery wastewater using a three-dimensional electrode reactor. Electrochim. Acta 2010, 55, 8615-8620. [CrossRef]

74. Fortuny, A.; Font, J.; Fabregat, A. Wet air oxidation of phenol using active carbon as catalyst. Appl. Catal. B Environ. 1998, 19, 165-173. [CrossRef]

75. Li, X.; Duan, P.; Lei, J.; Sun, Z.; Hu, X. Fabrication of $\mathrm{Ti} / \mathrm{TiO}_{2} / \mathrm{SnO}_{2}-\mathrm{Sb}-\mathrm{Cu}$ electrode for enhancing electrochemical degradation of ceftazidime in aqueous solution. J. Electroanal. Chem. 2019, 847, 113231. [CrossRef]

76. Duan, P.; Hu, X.; Ji, Z.; Yang, X.; Sun, Z. Enhanced oxidation potential of $\mathrm{Ti} / \mathrm{SnO}_{2}-\mathrm{Cu}$ electrode for electrochemical degradation of low-concentration ceftazidime in aqueous solution: Performance and degradation pathway. Chemosphere 2018, 212, 594-603. [CrossRef] [PubMed]

77. Turkay, O.; Barisci, S.; Ulusoy, E.; Dimoglo, A. Electrochemical Reduction of X-ray Contrast Iohexol at Mixed Metal Oxide Electrodes: Process Optimization and By-product Identification. Water Air Soil Pollut. 2018, 229, 170. [CrossRef]

78. Chen, X.; Chen, G. Fabrication and application of Ti/BDD for wastewater treatment. Synth. Diam. Film. Prep. Electrochem. Charact. Appl. 2011, 353-371. [CrossRef]

79. He, Y.; Huang, W.; Chen, R.; Zhang, W.; Lin, H.; Li, H. Anodic oxidation of aspirin on $\mathrm{PbO}_{2}$, $\mathrm{BDD}$ and porous Ti/BDD electrodes: Mechanism, kinetics and utilization rate. Sep. Purif. Technol. 2015, 156, 124-131. [CrossRef]

80. Sirés, I.; Oturan, N.; Oturan, M.A. Electrochemical degradation of $\beta$-blockers. Studies on single and multicomponent synthetic aqueous solutions. Water Res. 2010, 44, 3109-3120. [CrossRef] [PubMed]

81. Kandavelu, V.; Yoshihara, S.; Kumaravel, M.; Murugananthan, M. Anodic oxidation of isothiazolin-3-ones in aqueous medium by using boron-doped diamond electrode. Diam. Relat. Mater. 2016, 69, 152-159. [CrossRef]

82. Murugananthan, M.; Latha, S.; Raju, G.B.; Yoshihara, S. Anodic oxidation of ketoprofen-An anti-inflammatory drug using boron doped diamond and platinum electrodes. J. Hazard. Mater. 2010, 180, 753-758. [CrossRef]

83. Brocenschi, R.F.; Rocha-Filho, R.C.; Bocchi, N.; Biaggio, S.R. Electrochemical degradation of estrone using a boron-doped diamond anode in a filter-press reactor. Electrochim. Acta 2016, 197, 186-193. [CrossRef]

84. Coledam, D.A.; Pupo, M.M.; Silva, B.F.; Silva, A.J.; Eguiluz, K.I.; Salazar-Banda, G.R.; Aquino, J.M. Electrochemical mineralization of cephalexin using a conductive diamond anode: A mechanistic and toxicity investigation. Chemosphere 2017, 168, 638-647. [CrossRef] [PubMed]

85. Barışçı, S.; Turkay, O.; Ulusoy, E.; Şeker, M.G.; Yüksel, E.; Dimoglo, A. Electro-oxidation of cytostatic drugs: Experimental and theoretical identification of by-products and evaluation of ecotoxicological effects. Chem. Eng. J. 2018, 334, 1820-1827. [CrossRef]

86. Hussain, S.; Gul, S.; Steter, J.R.; Miwa, D.W.; Motheo, A.J. Route of electrochemical oxidation of the antibiotic sulfamethoxazole on a mixed oxide anode. Environ. Sci. Pollut. Res. 2015, 22, 15004-15015. [CrossRef] [PubMed]

87. Guo, X.; Li, D.; Wan, J.; Yu, X. Preparation and electrochemical property of $\mathrm{TiO}_{2} / \mathrm{Nano}_{\text {-graphite composite }}$ anode for electro-catalytic degradation of ceftriaxone sodium. Electrochim. Acta 2015, 180, 957-964. [CrossRef] 
88. Lin, H.; Wu, J.; Zhang, H. Degradation of clofibric acid in aqueous solution by an $\mathrm{EC} / \mathrm{Fe}^{3+} / \mathrm{PMS}$ process. Chem. Eng. J. 2014, 244, 514-521. [CrossRef]

89. Sifuna, F.W.; Orata, F.; Okello, V.; Jemutai-Kimosop, S. Comparative studies in electrochemical degradation of sulfamethoxazole and diclofenac in water by using various electrodes and phosphate and sulfate supporting electrolytes. J. Environ. Sci. Health Part A 2016, 51, 954-961. [CrossRef]

90. Tu, X.; Xiao, S.; Song, Y.; Zhang, D.; Zeng, P. Treatment of simulated berberine wastewater by electrochemical process with Pt/Ti anode. Environ. Earth Sci. 2015, 73, 4957-4966. [CrossRef]

91. Duan, P.; Yang, X.; Huang, G.; Wei, J.; Sun, Z.; Hu, X. $\mathrm{La}_{2} \mathrm{O}_{3}-\mathrm{CuO}_{2} / \mathrm{CNT}$ electrode with excellent electrocatalytic oxidation ability for ceftazidime removal from aqueous solution. Colloids Surf. A Physicochem. Eng. Asp. 2019, 569, 119-128. [CrossRef]

92. Duan, P.; Gao, S.; Li, X.; Sun, Z.; Hu, X. Preparation of $\mathrm{CeO}_{2}-\mathrm{ZrO}_{2}$ and titanium dioxide coated carbon nanotube electrode for electrochemical degradation of ceftazidime from aqueous solution. J. Electroanal. Chem. 2019, 841, 10-20. [CrossRef]

93. Díaz, E.; Stożek, S.; Patiño, Y.; Ordóñez, S. Electrochemical degradation of naproxen from water by anodic oxidation with multiwall carbon nanotubes glassy carbon electrode. Water Sci. Technol. Water Treat. 2019, 79, 480-488. [CrossRef]

94. Fabiańska, A.; Ofiarska, A.; Fiszka-Borzyszkowska, A.; Stepnowski, P.; Siedlecka, E.M. Electrodegradation of ifosfamide and cyclophosphamide at BDD electrode: Decomposition pathway and its kinetics. Chem. Eng. J. 2015, 276, 274-282. [CrossRef]

95. Domínguez, J.R.; Muñoz-Peña, M.J.; González, T.; Palo, P.; Cuerda-Correa, E.M. Parabens abatement from surface waters by electrochemical advanced oxidation with boron doped diamond anodes. Environ. Sci. Pollut. Res. 2016, 23, 20315-20330. [CrossRef]

96. Rabaaoui, N.; Allagui, M.S. Anodic oxidation of salicylic acid on BDD electrode: Variable effects and mechanisms of degradation. J. Hazard. Mater. 2012, 243, 187-192. [CrossRef] [PubMed]

97. Indermuhle, C.; Martin de Vidales, M.J.; Saez, C.; Robles, J.; Canizares, P.; Garcia-Reyes, J.F.; Molina-Diaz, A.; Comninellis, C.; Rodrigo, M.A. Degradation of caffeine by conductive diamond electrochemical oxidation. Chemosphere 2013, 93, 1720-1725. [CrossRef]

98. Ambuludi, S.L.; Panizza, M.; Oturan, N.; Ozcan, A.; Oturan, M.A. Kinetic behavior of anti-inflammatory drug ibuprofen in aqueous medium during its degradation by electrochemical advanced oxidation. Environ. Sci. Pollut. Res. Int. 2013, 20, 2381-2389. [CrossRef] [PubMed]

99. Da Silva Duarte, J.L.; Solano, A.M.S.; Arguelho, M.L.; Tonholo, J.; Martínez-Huitle, C.A.; e Silva, C.L.d.P. Evaluation of treatment of effluents contaminated with rifampicin by Fenton, electrochemical and associated processes. J. Water Process Eng. 2018, 22, 250-257. [CrossRef]

100. Coledam, D.A.; Aquino, J.M.; Silva, B.F.; Silva, A.J.; Rocha-Filho, R.C. Electrochemical mineralization of norfloxacin using distinct boron-doped diamond anodes in a filter-press reactor, with investigations of toxicity and oxidation by-products. Electrochim. Acta 2016, 213, 856-864. [CrossRef]

101. Steter, J.R.; Rocha, R.S.; Dionísio, D.; Lanza, M.R.; Motheo, A.J. Electrochemical oxidation route of methyl paraben on a boron-doped diamond anode. Electrochim. Acta 2014, 117, 127-133. [CrossRef]

102. Fabiańska, A.; Białk-Bielińska, A.; Stepnowski, P.; Stolte, S.; Siedlecka, E.M. Electrochemical degradation of sulfonamides at BDD electrode: Kinetics, reaction pathway and eco-toxicity evaluation. J. Hazard. Mater. 2014, 280, 579-587. [CrossRef]

103. Brinzila, C.; Monteiro, N.; Pacheco, M.; Ciríaco, L.; Siminiceanu, I.; Lopes, A. Degradation of tetracycline at a boron-doped diamond anode: Influence of initial $\mathrm{pH}$, applied current intensity and electrolyte. Environ. Sci. Pollut. Res. 2014, 21, 8457-8465. [CrossRef]

104. Haidar, M.; Dirany, A.; Sirés, I.; Oturan, N.; Oturan, M.A. Electrochemical degradation of the antibiotic sulfachloropyridazine by hydroxyl radicals generated at a BDD anode. Chemosphere 2013, 91, 1304-1309. [CrossRef]

105. González, T.; Domínguez, J.R.; Palo, P.; Sánchez-Martín, J. Conductive-diamond electrochemical advanced oxidation of naproxen in aqueous solution: Optimizing the process. J. Chem. Technol. Biotechnol. Adv. 2011, 86, 121-127. [CrossRef]

106. Domínguez, J.R.; González, T.; Palo, P.; Sánchez-Martín, J. Electrochemical advanced oxidation of carbamazepine on boron-doped diamond anodes. Influence of operating variables. Ind. Eng. Chem. Res. 2010, 49, 8353-8359. [CrossRef] 
107. Sun, Y.; Li, P.; Zheng, H.; Zhao, C.; Xiao, X.; Xu, Y.; Sun, W.; Wu, H.; Ren, M. Electrochemical treatment of chloramphenicol using Ti-Sn $/ \gamma-\mathrm{Al}_{2} \mathrm{O}_{3}$ particle electrodes with a three-dimensional reactor. Chem. Eng. J. 2017, 308, 1233-1242. [CrossRef]

108. Hu, X.; Yu, Y.; Sun, Z. Preparation and characterization of cerium-doped multiwalled carbon nanotubes electrode for the electrochemical degradation of low-concentration ceftazidime in aqueous solutions. Electrochim. Acta 2016, 199, 80-91. [CrossRef]

109. Yang, W.; Zhou, M.; Oturan, N.; Li, Y.; Su, P.; Oturan, M.A. Enhanced activation of hydrogen peroxide using nitrogen doped graphene for effective removal of herbicide 2, 4-D from water by iron-free electrochemical advanced oxidation. Electrochim. Acta 2019, 297, 582-592. [CrossRef]

110. Al-Qaim, F.F.; Mussa, Z.H.; Othman, M.R.; Abdullah, M.P. Removal of caffeine from aqueous solution by indirect electrochemical oxidation using a graphite-PVC composite electrode: A role of hypochlorite ion as an oxidising agent. J. Hazard. Mater. 2015, 300, 387-397. [CrossRef] [PubMed]

111. Frontistis, Z.; Antonopoulou, M.; Yazirdagi, M.; Kilinc, Z.; Konstantinou, I.; Katsaounis, A.; Mantzavinos, D. Boron-doped diamond electrooxidation of ethyl paraben: The effect of electrolyte on by-products distribution and mechanisms. J. Environ. Manag. 2017, 195, 148-156. [CrossRef] [PubMed]

112. Palo, P.; Domínguez, J.R.; González, T.; Sánchez-Martin, J.; Cuerda-Correa, E.M. Feasibility of electrochemical degradation of pharmaceutical pollutants in different aqueous matrices: Optimization through design of experiments. J. Environ. Sci. Health Part A 2014, 49, 843-850. [CrossRef]

113. De Vidales, M.J.M.; Millán, M.; Sáez, C.; Pérez, J.F.; Rodrigo, M.A.; Cañizares, P. Conductive diamond electrochemical oxidation of caffeine-intensified biologically treated urban wastewater. Chemosphere 2015, 136, 281-288. [CrossRef]

114. Zaghdoudi, M.; Fourcade, F.; Soutrel, I.; Floner, D.; Amrane, A.; Maghraoui-Meherzi, H.; Geneste, F. Direct and indirect electrochemical reduction prior to a biological treatment for dimetridazole removal. J. Hazard. Mater. 2017, 335, 10-17. [CrossRef]

115. Belkheiri, D.; Fourcade, F.; Geneste, F.; Floner, D.; Aït-Amar, H.; Amrane, A. Feasibility of an electrochemical pre-treatment prior to a biological treatment for tetracycline removal. Sep. Purif. Technol. 2011, 83, 151-156. [CrossRef]

116. Yahiaoui, I.; Aissani-Benissad, F.; Fourcade, F.; Amrane, A. Removal of tetracycline hydrochloride from water based on direct anodic oxidation $\left(\mathrm{Pb} / \mathrm{PbO}_{2}\right.$ electrode) coupled to activated sludge culture. Chem. Eng. J. 2013, 221, 418-425. [CrossRef]

117. Rodríguez-Nava, O.; Ramírez-Saad, H.; Loera, O.; González, I. Evaluation of the simultaneous removal of recalcitrant drugs (bezafibrate, gemfibrozil, indomethacin and sulfamethoxazole) and biodegradable organic matter from synthetic wastewater by electro-oxidation coupled with a biological system. Environ. Technol. 2016, 37, 2964-2974. [CrossRef] [PubMed]

118. García-Gómez, C.; Drogui, P.; Seyhi, B.; Gortáres-Moroyoqui, P.; Buelna, G.; Estrada-Alvgarado, M.I.; Álvarez, L.H. Combined membrane bioreactor and electrochemical oxidation using $\mathrm{Ti} / \mathrm{PbO}_{2}$ anode for the removal of carbamazepine. J. Taiwan Inst. Chem. Eng. 2016, 64, 211-219. [CrossRef]

119. Ouarda, Y.; Tiwari, B.; Azais, A.; Vaudreuil, M.A.; Ndiaye, S.D.; Drogui, P.; Tyagi, R.D.; Sauve, S.; Desrosiers, M.; Buelna, G.; et al. Synthetic hospital wastewater treatment by coupling submerged membrane bioreactor and electrochemical advanced oxidation process: Kinetic study and toxicity assessment. Chemosphere 2018, 193, 160-169. [CrossRef]

120. Ensano, B.M.B.; Borea, L.; Naddeo, V.; Belgiorno, V.; de Luna, M.D.G.; Balakrishnan, M.; Ballesteros, F.C., Jr. Applicability of the electrocoagulation process in treating real municipal wastewater containing pharmaceutical active compounds. J. Hazard. Mater. 2019, 361, 367-373. [CrossRef]

121. Borea, L.; Ensano, B.M.B.; Hasan, S.W.; Balakrishnan, M.; Belgiorno, V.; de Luna, M.D.G.; Ballesteros, F.C.; Naddeo, V. Are pharmaceuticals removal and membrane fouling in electromembrane bioreactor affected by current density? Sci. Total Environ. 2019, 692, 732-740. [CrossRef]

(C) 2020 by the authors. Licensee MDPI, Basel, Switzerland. This article is an open access article distributed under the terms and conditions of the Creative Commons Attribution (CC BY) license (http://creativecommons.org/licenses/by/4.0/). 